\title{
Concentrations and solubility of trace elements in fine particles at a mountain site, southern China: regional sources and cloud processing
}

\author{
T. Li ${ }^{1}$, Y. Wang ${ }^{1}$, W. J. Li ${ }^{2}$, J. M. Chen ${ }^{1,2}$, T. Wang ${ }^{3}$, and W. X. Wang ${ }^{2}$ \\ ${ }^{1}$ School of Environmental Science and Engineering, Shandong University, Jinan, Shandong 250100, China \\ ${ }^{2}$ Environment Research Institute, Shandong University, Jinan, Shandong 250100, China \\ ${ }^{3}$ Department of Civil and Environmental Engineering, the Hong Kong Polytechnic University, Hong Kong, China
}

Correspondence to: Y. Wang (wy@sdu.edu.cn)

Received: 10 February 2015 - Published in Atmos. Chem. Phys. Discuss.: 5 May 2015

Revised: 31 July 2015 - Accepted: 3 August 2015 - Published: 13 August 2015

\begin{abstract}
The concentrations and solubility of twelve trace elements in $\mathrm{PM}_{2.5}$ at Mt. Lushan, southern China, were investigated during the summer of 2011 and the spring of 2012. The average $\mathrm{PM}_{2.5}$ mass was $55.2 \pm 20.1 \mu \mathrm{g} \mathrm{m}^{-3}$ during the observation period. Temporal variations of all trace elements including total and water-soluble fractions with several dust storm spikes in total fractions of $\mathrm{Al}$ and $\mathrm{Fe}$ were observed. The enrichment factor $(\mathrm{EF})$ values were 1 order of magnitude higher for the water-soluble fractions versus the total fractions of trace elements. Four major emission sources, namely nonferrous metal mining and smelting (for $\mathrm{Cr}$, As, $\mathrm{Ba}$ and parts of $\mathrm{Zn}$ ), coal combustion (for $\mathrm{Pb}, \mathrm{Zn}, \mathrm{Se}, \mathrm{Cu}$ and $\mathrm{Mn}$ ), crustal materials (for $\mathrm{Al}$ and $\mathrm{Fe}$ ) and municipal solid waste incineration (for $\mathrm{Cd}$ and $\mathrm{Mo}$ ), were classified by principal component analysis (PCA). Trajectory cluster analysis and the potential source contribution function (PSCF) consistently identified the Yangtze River delta (YRD), the Pearl River delta (PRD), and the neighbouring provinces of Mt. Lushan as the major source regions and transport pathways for anthropogenic elements. Northern China was identified as a major source region for crustal elements. It should be noted that apart from the YRD, the area around Mt. Lushan has become the most significant contributor to the solubility of most trace elements. Element solubility can be partially determined by emission sources. However, enhanced solubility of trace elements corresponding to increased concentrations of sulfate after the occurrence of cloud events indicated significant effects of cloud processing on aerosol element dissolution. Metal particles mixed with sulfate in cloud droplet
\end{abstract}

residues were further investigated through transmission electron microscopy (TEM) analysis. Irreversible alteration of particle morphology by cloud processing was confirmed to be highly responsible for the enhancement of trace element solubility. The findings from this study imply an important role of regional anthropogenic pollution and cloud processing in the evolution of aerosol trace element solubility during transport in the troposphere.

\section{Introduction}

Epidemiologic studies have associated long-term exposure to highly inhalable ambient fine particulate matter $(\leq 2.5 \mu \mathrm{m}$, $\mathrm{PM}_{2.5}$ ) with many adverse health outcomes such as cardiovascular and respiratory morbidity and mortality, whether in urban or rural areas (Hoek et al., 2013; Cao et al., 2012; Weichenthal et al., 2014). Sustained exposure to high concentrations of PM air pollution has been suggested to contribute to a decrease in life expectancy of approximately 3 years in China (Chen et al., 2013). The long atmospheric lifetimes of days give fine particles opportunities to be subject to longrange transboundary or intercontinental transport in the air and to deposition toward remote areas, carrying abundant anthropogenic pollutants and affecting ecosystems (Mahowald, 2011). Fine particles are also responsible for regional and global climate change and the hydrologic cycle interference through radiative forcing directly by reflecting sunlight and 
indirectly by changing cloud properties and precipitation acting as cloud condensation nuclei (Kaufman et al., 2002).

Although trace elements constitute only a small proportion of fine particle mass, their negative impacts on human health and ecosystems have attracted considerable attention because of their toxicity and bioaccumulation by inhalation and deposition. Toxicological and epidemiologic studies often suggest trace metals, particularly water-soluble metals, which are more easily bioavailable, as the critical components harmful to the cardiopulmonary system through oxidative chemistry (Cakmak et al., 2014; Costa and Dreher, 1997). Soluble trace elements, especially the transition metals, are likely to be the primary drivers of the generation of reactive oxygen species, inducing cellular inflammation (Charrier et al., 2014; Cheung et al., 2012; Shafer et al., 2010). Besides, trace metal ions also play an important catalysis role in secondary aqueous-phase (Harris et al., 2013) and particle-phase (Clements et al., 2013) sulfate formation, heterogeneous production and elimination of gas-phase hydrogen peroxide (Guo et al., 2014a), as well as multiphase cloud chemistry (Deguillaume et al., 2004). Importantly, most anthropogenic trace elements in ambient air are considered to be mainly concentrated on fine particles, strengthening their toxicity. Therefore, understanding both the concentrations and water solubility of fine particle trace elements is essential for revealing their bioavailability in ambient environments and reactivity in atmospheric chemistry.

Diverse characteristics and sources of atmospheric trace elements have been investigated in various areas. For example, regional background, and urban and industrial sites in Spain were found to have clearly different concentration levels and source origins of trace elements in PM (Querol et al., 2007); technogenic metalliferous fine aerosols observed in urban Montseny demonstrated the spatiotemporal variability of trace metal pollution (Moreno et al., 2011); traffic, static combustion and crustal dust were suggested as the main sources of $\mathrm{Fe}, \mathrm{Zn}, \mathrm{Pb}$ and $\mathrm{Cu}$ in $\mathrm{PM}_{2.5}$ in an urban background area in Edinburgh (Heal et al., 2005); meanwhile, stationary industrial emissions from coal combustion were confirmed as the contributor to substantial atmospheric lead pollution of $\mathrm{PM}_{2.5}$ in Shanghai (Chen et al., 2008). The United States has already established a spatially gridded national emissions inventory of $\mathrm{PM}_{2.5}$ trace elements in speciation profiles with the dominant sources of crustal, biomass burning, coal combustion and industrial processing (Reff et al., 2009). In Asia, atmospheric metallic element pollution by human activities has been surveyed, with the highest metal concentrations occurring in China (Fang et al., 2010). Coal combustion, nonferrous metal smelting and iron and steel manufacturing are found to be the major disproportionate sources of atmospheric hazardous trace elements in China according to the latest anthropogenic emissions inventory, which highlighted an increasing trend in air pollution by toxic heavy metals (Cheng et al., 2015).
Recently, many field observations have found that even remote mountains and oceans have been polluted by anthropogenic trace elements in fine particles, significantly confirming the contributions of long-range transport (Deng et al., 2011; Schwab, 2004; Fomba et al., 2013). A few studies on dust in Asia (Takahashi et al., 2011; Hsu et al., 2013) indicate that the water solubility of trace elements is different for various emission sources and could be modified further during long-range transport, probably by photochemical aging and cloud processing, etc. (Hsu et al., 2010). However, little information about fine particle trace elements has been reported with regard to the identification of source regions or pathways, and the main mechanism of trace element dissolution by atmospheric processing is still unclear.

This paper provides a data set of the concentration and solubility (defined as the proportion of dissolved element concentration in total content) of trace elements in fine particles at Mt. Lushan, a high, rural mountain within an acid precipitation area in southern China. We focused on identifying the potential source region distributions for individual elements, aiming to evaluate the contributions of local, regional and long-range transport. Regional contributions to element solubility were also preliminarily investigated. One condensation-evaporation cloud cycle can increase aerosol solubility, and atmospheric aerosols may experience up to ten cloud cycles before removal (Desboeufs et al., 2001; Spokes et al., 1994); hence, we intensively discussed the influence of actual cloud processing on the alteration of fine particle trace element solubility, considering the rather frequent cloud events at Mt. Lushan. The size, mixing state and chemical composition of individual metal particles in cloud residues were detected using transmission electron microscopy (TEM) to investigate the effects of microphysical properties on the evolution of element solubility.

\section{Methodology}

\subsection{Site description}

Mt. Lushan is one of the National Geoparks of China, with an area of $302 \mathrm{~km}^{2}$, and is situated in northern Jiangxi Province, southern China, adjacent to the Yangtze River and Poyang Lake (Fig. 1). Mt. Lushan is significantly influenced by a subtropical monsoon and mountain climate, with frequent cloud events occurring from spring to autumn. The sampling site is located in Guniubei $\left(115^{\circ} 59^{\prime} \mathrm{E}, 29^{\circ} 35^{\prime} \mathrm{N}\right.$; 1165 m a.s.l.; see Fig. S1 in the Supplement), the top of Guling, where most residents work in tourism or related services and little pollution is produced. There are intensive coal-fired power plants located in the eastern coastal area, and abundant mineral resources and many large non-ferrous industries exist in Jiangxi and in neighbouring provinces. Therefore, Mt. Lushan is a favourable platform for observing the long-range transport of regional air pollution and for evaluating the in- 


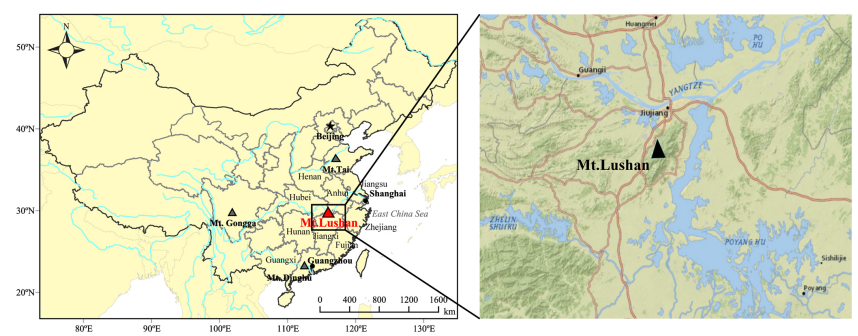

Figure 1. The location of Mt. Lushan and the adjacent Yangtze River and Poyang Lake.

fluence of atmospheric particles on the local ecological environment.

\subsection{Sample collection}

Daily $\mathrm{PM}_{2.5}$ samples were collected on quartz fibre filters (MK 360, $90 \mathrm{~mm}$, Munktell, Switzerland) during the summer of 2011 (8 August-23 September) and the spring of 2012 (18 March-20 May). The filters were heated at $500^{\circ} \mathrm{C}$ for $3 \mathrm{~h}$ prior to sampling, subsequently balanced at $25^{\circ} \mathrm{C}$ and $50 \pm 5 \%$ relative humidity for at least $24 \mathrm{~h}$ and weighed three times before and after collection. The sampling procedures were conducted during non-rainy and non-cloudy periods by employing a $\mathrm{PM}_{2.5}$ impactor (TH-150A, Tianhong Co., China) with a medium flow rate of $100 \mathrm{~L} \mathrm{~min}^{-1}$. Seventy-six valid ambient samples and six blank filters were obtained and stored in the dark and at $-20^{\circ} \mathrm{C}$ for laboratory analysis.

Cloud water was collected by an improved single-stage Caltech Active Strand Cloudwater Collector (CASCC2, Demoz et al., 1996). Air with cloud droplets is inhaled into the instrument with a sampling flow rate of $24.5 \mathrm{~m}^{3} \mathrm{~min}^{-1}$ and impacted on vertical $508 \mu \mathrm{m}$ diameter Teflon strands. The droplets are then collected into a Teflon sample trough along the strands and flow into a $500 \mathrm{~mL}$ high-density polyethylene bottle. The theoretical sampling efficiency for a size cut of $3.5 \mu \mathrm{m}$ droplet diameter corresponds to $50 \%$. In this study, the sampling interval of cloud water was $2-3 \mathrm{~h}$. The samples were immediately filtered and stored in brown glass bottles at $4{ }^{\circ} \mathrm{C}$ with preservation of $1 \% \mathrm{v} / \mathrm{v}$ high pure hydrochloric acid.

The sampling system of cloud residues (Fig. S2, Li et al., 2011) was employed to obtain individual cloud residues in cloud events on 11 September 2011 and 18 April 2012. The moisture of the cloud droplets is removed by a diffusion dryer filled with desiccant (silica gel) to prevent the impact of the water vapor on TEM grids. Then, the individual residues are collected onto TEM grids using a single-stage cascade impactor with a $0.5 \mathrm{~mm}$ diameter jet nozzle. The calculated effective size $d_{50}$ for a cloud droplet is about $0.7 \mu \mathrm{m}$ and the collection efficiency is estimated to be 5-10\%. For cloud residues at Mt. Lushan, a low sampling flow rate of $0.5 \mathrm{~L} \mathrm{~min}^{-1}$ and an optimum sampling time of about $12 \mathrm{~min}$ were applied, neither destroying the TEM grids nor overlapping each individual residue. An optical microscopy with magnification from $\times 500$ to $\times 1200$ was operated on site to check the integrity of carbon film and particle distribution on the TEM grid. If suitable, the grids were sealed in a dry plastic tube and stored in desiccators at $25^{\circ} \mathrm{C}$ and $20 \pm 3 \% \mathrm{RH}$ until the laboratory analysis. Otherwise, another satisfactory sample shall be collected and preserved.

\subsection{Extraction procedure}

\subsubsection{Total fraction (acid)}

To obtain the total concentration of trace elements in fine particles with the least loss of semi-volatile elements, onequarter of the samples and blank filters was digested with an acid mixture $\left(5 \mathrm{~mL} 65 \% \mathrm{HNO}_{3}\right.$ and $2 \mathrm{~mL} 30 \% \mathrm{H}_{2} \mathrm{O}_{2}$, guaranteed reagent grade, Kemiou Co., China) in closed Teflon vessels using a microwave digestion system according to a controlled gradient temperature procedure, reaching $120^{\circ} \mathrm{C}$ in $5 \mathrm{~min}$ and remaining there for $5 \mathrm{~min}$, then reaching $160^{\circ} \mathrm{C}$ in $5 \mathrm{~min}$ and remaining there for $2 \mathrm{~min}$, and finally reaching $185^{\circ} \mathrm{C}$ in $5 \mathrm{~min}$ and remaining there for $15 \mathrm{~min}$. After cooling to room temperature, the solutions were filtered and subsequently diluted to $25 \mathrm{~mL}$ with high-purity deionised water $(\geq 18 \mathrm{M} \Omega \mathrm{CM})$ in acid-cleaned brown glass bottles.

\subsubsection{Water-soluble fraction (water)}

Half of the samples and blank filters were extracted with $50 \mathrm{~mL}$ high-purity deionised water $(\geq 18 \mathrm{M} \Omega \mathrm{CM})$ using ultra-sonication for $1 \mathrm{~h}$ followed by filtration. Solutions of approximately $25 \mathrm{~mL}$ were preserved in acid-cleaned brown glass bottles with $1 \% v / v$ high pure hydrochloric acid to lessen adsorption of the elements by the glass walls. All solutions were stored at $4{ }^{\circ} \mathrm{C}$ until instrument analysis.

\subsection{Chemical and physical analysis}

The concentrations of the total and water-soluble fractions of twelve trace elements (including $\mathrm{Al}, \mathrm{Cr}, \mathrm{Mn}, \mathrm{Fe}, \mathrm{Cu}, \mathrm{Zn}$, $\mathrm{As}, \mathrm{Se}, \mathrm{Mo}, \mathrm{Cd}, \mathrm{Ba}$ and $\mathrm{Pb}$ ) were measured by inductively coupled plasma mass spectrometry (ICP-MS, Agilent 7500a) based on the EPA 200.8 method using internal standard substances of $\mathrm{Li}, \mathrm{Sc}, \mathrm{Ge}, \mathrm{Y}, \mathrm{In}, \mathrm{Tb}$ and $\mathrm{Bi}$ to eliminate matrix interference. National standard materials (soil, GSS-4, China) were digested for calculating element recoveries by the acid extraction method. All recoveries were found to be a little lower than $100 \%$ (Table S1 in the Supplement), ranging from $93.0 \%$ for $\mathrm{Cd}$ to $72.7 \%$ for Se, primarily ascribed to volatilisation losses and acid mixture that are not strong enough to release all mineral constituents from the silica matrix into the solution. Reagent and filter blanks were also prepared and analysed for background element content. The detection limits of the ICP-MS analysis for the total fraction elements determined were calculated as 3 times the standard deviation 
$(3 \delta)$ of the six blank values (Table S1). Trace element concentrations in cloud water samples were similarly determined by ICP-MS.

Individual metal particles in cloud residues on the TEM grids were analysed with a JEM-2100 TEM operating at $200 \mathrm{kV}$ accompanied by a semi-quantitative determination of elemental composition by an energy-dispersive X-ray spectrometer (EDS) that can detect elements heavier than carbon. EDS spectra were collected for only $15 \mathrm{~s}$ to minimise radiation exposure and potential beam damage. Copper could not be analysed because of interference from the copper TEM grid.

\subsection{Meteorology}

Meteorology parameters during the observation periods and two cloud events were obtained from the local meteorological station (listed in Table S2). Generally, summer days exhibited higher temperature, relative humidity and wind speed than spring. In particular, the cloud events were characterised by high humidity ( $>99 \%$ ), low wind speed (about $1.0 \mathrm{~m} \mathrm{~s}^{-1}$ ) and bad visibility (nearly $0 \mathrm{~km}$ ).

\subsection{Backward trajectories and potential source contribution function (PSCF)}

The Hybrid Single-Particle Lagrangian Integrated Trajectory (HYSPLIT) model (PC Version 4.8) developed by the National Oceanic and Atmospheric Administration Air Resources Laboratory (NOAA-ARL) (Draxler and Rolph, 2014) was used to reconstruct the three-dimensional backward trajectories for the purpose of identifying the possible impacts of long-range transport. Three-day air-mass backward trajectories initiated every $12 \mathrm{~h}$ arriving at Mt. Lushan at the height of $1165 \mathrm{~m}$ a.s.l. were calculated, and five mean trajectory clusters were classified.

The potential source contribution function (PSCF) analysis developed by Hopke et al. (1995) was computed using a geographical information system-based software, TrajStat (Wang et al., 2009), with the calculated backward trajectories and measured atmospheric pollutant concentrations representing the conditional probability that air parcels may be responsible for concentrations higher than the criterion level during transport to the receptor site. The PSCF value for the $i j$ th grid cell is defined as

$\operatorname{PSCF}_{i j}=\frac{m_{i j}}{n_{i j}}$,

where $n_{i j}$ is the total number of trajectory segment endpoints that fall in the $i j$ th cell and $m_{i j}$ is the number of endpoints for the same cell with arrival times at the sampling site corresponding to pollutant concentrations higher than an arbitrary criterion value. In this study, the total number of endpoints was 18998 , and the geophysical domain $\left(90-130^{\circ} \mathrm{E}\right.$, $15-45^{\circ} \mathrm{N}$ ) was divided into 4800 grid cells with a $0.5^{\circ} \times 0.5^{\circ}$ resolution. The average concentrations were set as criteria for $\mathrm{PM}_{2.5}$ and each trace element, except for $\mathrm{Al}$, for which the 75th percentile was better to distinguish between larger versus moderate regional sources. The PSCF values were multiplied by an arbitrary weight function $W_{i j}$ to reduce the effect of small values of $n_{i j}$ and to better reflect the uncertainty in values for these cells (Polissar et al., 2001). The weighting function reduced the PSCF values when the total number of the endpoints in a particular cell $\left(n_{i j}\right)$ was less than approximately 3 times the average value $\left(n_{\text {Ave }}\right)$ of the endpoints per each cell, defined as

$$
W_{i j}=\left\{\begin{array}{cc}
1.00 & n_{i j}>3 n_{\text {Ave }} \\
0.70 & 1.5 n_{\text {Ave }}<n_{i j} \leq 3 n_{\text {Ave }} \\
0.42 & n_{\text {Ave }}<n_{i j} \leq 1.5 n_{\text {Ave }} \\
0.17 & 0<n_{i j} \leq n_{\text {Ave }}
\end{array}\right.
$$

\section{Results and discussion}

\subsection{Elemental composition}

\subsubsection{General characterisation}

The ambient atmospheric concentrations of $\mathrm{PM}_{2.5}$ and trace elements including total and water-soluble fractions at Mt. Lushan are summarised in Table 1, and the comparisons with typical mountains and megacities in China are listed in Table S3. The average $\mathrm{PM}_{2.5}$ concentration at Mt. Lushan in spring $\left(54.7 \mu \mathrm{g} \mathrm{m}^{-3}\right)$ was approximately that of summer $\left(55.9 \mathrm{\mu g} \mathrm{m}^{-3}\right)$, more than twice the WHO air quality guideline for daily $\mathrm{PM}_{2.5}$ of $25 \mu \mathrm{g} \mathrm{m}^{-3}$, but still lower than many urban sites at ground level such as Beijing $\left(118.5 \mu \mathrm{g} \mathrm{m}^{-3}\right)$ and Guangzhou $\left(81.7 \mu \mathrm{g} \mathrm{m}^{-3}\right.$ ) (Yang et al., 2011). It was clearly contrary to Mt. Tai (Deng et al., 2011), where $\mathrm{PM}_{2.5}$ exhibited a concentration 2-3 times higher in summer $\left(123.1 \mu \mathrm{g} \mathrm{m}^{-3}\right)$ than in spring $\left(46.6 \mu \mathrm{g} \mathrm{m}^{-3}\right)$, suggesting a less-pronounced seasonal variation of $\mathrm{PM}_{2.5}$ at Mt. Lushan.

The total fraction concentrations of twelve trace elements in spring were comparable with those in summer at Mt. Lushan, with the exception of higher $\mathrm{Al}$ in spring. Overall, elements $\mathrm{Al}$ and $\mathrm{Fe}$ contributed to the highest concentration, and the other elements decreased from $258.3 \mathrm{ng} \mathrm{m}^{-3}$ for $\mathrm{Zn}$ to $2.0 \mathrm{ng} \mathrm{m}^{-3}$ for Mo. The dominant elements ( $\mathrm{Al}, \mathrm{Fe}$ and $\mathrm{Zn}$ ) exhibited significantly lower concentrations at Mt. Lushan than Mt. Tai $\left(1200 \mathrm{ng} \mathrm{m}^{-3}\right.$ for $\mathrm{Al}, 810 \mathrm{ng} \mathrm{m}^{-3}$ for $\mathrm{Fe}$ and $400 \mathrm{ng} \mathrm{m}^{-3}$ for $\mathrm{Zn}$ ) (Deng et al., 2011) and slightly higher than Mt. Gongga (295.8 $\mathrm{ng} \mathrm{m}^{-3}$ for Al, $224.0 \mathrm{ng} \mathrm{m}^{-3}$ for $\mathrm{Fe}$ and $154.6 \mathrm{ng} \mathrm{m}^{-3}$ for $\mathrm{Zn}$ ) (Yang et al., 2009a), probably due to the geomorphology and climatology biases. As shown in Table S3, all elements (except Ba) have lower concentration levels in comparison with Mt. Dinghu, a national nature reserve influenced by atmospheric pollution (Yang et al., 2009b) and with typical megacities in China such as Beijing, Guangzhou (Yang et al., 2011) and Shanghai (Chen et 
Table 1. Concentrations (mean $\pm \mathrm{SD}$ ) of $\mathrm{PM}_{2.5}\left(\mu \mathrm{g} \mathrm{m}^{-3}\right)$ and trace elements $\left(\mathrm{ng} \mathrm{m}^{-3}\right)$ including total and water-soluble fraction at Mt. Lushan.

\begin{tabular}{|c|c|c|c|c|c|c|}
\hline & \multicolumn{2}{|c|}{ Overall } & \multicolumn{2}{|c|}{ Summer 2011} & \multicolumn{2}{|c|}{ Spring 2012} \\
\hline & Total & Water soluble & Total & Water soluble & Total & Water soluble \\
\hline $\mathrm{PM}_{2.5}$ & \multicolumn{2}{|c|}{$55.2 \pm 20.1$} & \multicolumn{2}{|c|}{$55.9 \pm 21.8$} & \multicolumn{2}{|c|}{$54.7 \pm 18.9$} \\
\hline $\mathrm{Al}$ & $449.1 \pm 441.1$ & $73.3 \pm 93.5$ & $369.1 \pm 464.4$ & $108.0 \pm 121.7$ & $515.1 \pm 415.2$ & $48.9 \pm 57.3$ \\
\hline $\mathrm{Fe}$ & $331.1 \pm 236.2$ & $71.5 \pm 70.5$ & $330.4 \pm 250.9$ & $101.9 \pm 70.5$ & $331.6 \pm 227.3$ & $15.7 \pm 12.9$ \\
\hline $\mathrm{Zn}$ & $258.3 \pm 162.8$ & $172.9 \pm 105.8$ & $274.3 \pm 129.5$ & $211.9 \pm 104.4$ & $245.3 \pm 186.1$ & $142.3 \pm 97.5$ \\
\hline $\mathrm{Pb}$ & $68.2 \pm 49.3$ & $29.4 \pm 23.8$ & $65.4 \pm 47.3$ & $37.8 \pm 27.5$ & $70.5 \pm 51.4$ & $22.7 \pm 18.3$ \\
\hline $\mathrm{Ba}$ & $63.8 \pm 54.2$ & $23.4 \pm 17.0$ & $66.0 \pm 71.1$ & $19.3 \pm 15.0$ & $61.9 \pm 33.6$ & $26.7 \pm 18.0$ \\
\hline $\mathrm{Mn}$ & $22.2 \pm 12.2$ & $15.5 \pm 8.1$ & $24.7 \pm 12.5$ & $19.0 \pm 8.8$ & $20.2 \pm 11.6$ & $12.8 \pm 6.3$ \\
\hline As & $21.5 \pm 19.6$ & $14.8 \pm 11.9$ & $22.3 \pm 16.3$ & $12.40 \pm 6.1$ & $20.9 \pm 22.2$ & $17.0 \pm 15.1$ \\
\hline $\mathrm{Cr}$ & $13.7 \pm 17.2$ & $0.7 \pm 0.5$ & $18.2 \pm 19.5$ & $0.8 \pm 0.6$ & $9.6 \pm 13.8$ & $0.3 \pm 0.1$ \\
\hline $\mathrm{Cu}$ & $12.4 \pm 9.6$ & $9.9 \pm 8.9$ & $13.2 \pm 6.4$ & $10.7 \pm 6.9$ & $11.7 \pm 11.6$ & $9.3 \pm 10.2$ \\
\hline $\mathrm{Se}$ & $7.0 \pm 3.3$ & $5.0 \pm 2.9$ & $7.6 \pm 2.9$ & $5.2 \pm 2.9$ & $6.5 \pm 3.5$ & $4.8 \pm 2.9$ \\
\hline $\mathrm{Cd}$ & $2.5 \pm 1.8$ & $1.3 \pm 0.9$ & $2.8 \pm 1.9$ & $1.3 \pm 0.6$ & $2.2 \pm 1.6$ & $1.2 \pm 1.1$ \\
\hline Mo & $2.0 \pm 2.0$ & $0.6 \pm 0.4$ & $2.6 \pm 2.2$ & $0.7 \pm 0.5$ & $1.5 \pm 1.7$ & $0.5 \pm 0.3$ \\
\hline
\end{tabular}

al., 2008). For water-soluble fractions, $\mathrm{Zn}$ transformed into the primary elements, followed by $\mathrm{Al}$ and $\mathrm{Fe}$, with higher concentrations in summer than spring; other trace elements (from $\mathrm{Pb}$ to $\mathrm{Mo}$ ) were still comparable between summer and spring.

\subsubsection{Temporal variations}

Figure 2 displays the temporal variations of trace element concentrations in $\mathrm{PM}_{2.5}$ at Mt. Lushan for total and watersoluble fractions during the sampling campaigns. Most total fraction elements exhibited more intense variances in spring than in summer, with unique temporal patterns such as the highly variable pattern observed for aluminium and the relatively steady pattern of arsonium. Similar temporal patterns were observed for the water-soluble and total fractions for most elements, except for $\mathrm{Al}$ and $\mathrm{Fe}$, which had drastic variations with many spike episodes for total fractions but lower constant concentration for water-soluble fractions. The dependence of temporal variations of water-soluble elements on their total fractions was also examined (Fig. S3). The concentrations of water-soluble $\mathrm{Zn}, \mathrm{Cu}, \mathrm{Mn}, \mathrm{As}$, Se and $\mathrm{Cd}$ were found to be rather consistent with their total fraction according to their high correlations $\left(R^{2}=0.50-0.78\right)$, whereas there was only a weak association between the total concentrations and water-soluble fractions of $\mathrm{Al}, \mathrm{Fe}$ and $\mathrm{Cr}$.

Several spikes in element concentration were observed in specific periods. The first spike (Spike I) for all elements during 11-13 August 2011 was ascribed to the short sampling time due to the interruption by an unexpected thundershower. However, the significantly elevated total concentrations of Al, Fe and Mn during 23-25 March 2012 (Spike II) and 25-26 April 2012 (Spike III) with no distinct elevation in the other elements were observed (Fig. 2), likely contributed by the dust storms originating from the Gobi Desert and the
Taklimakan Desert in spring according to the MODIS image, the OMI Aerosol Index and air-mass backward trajectory analysis (Fig. S4). These features were similar to the Asian Dust observed at Huaniao Island in the East China Sea, where concentrations of $\mathrm{Al}, \mathrm{Fe}, \mathrm{Mn}$ and $\mathrm{Ba}$ 3-4 times higher were observed with no significant difference for $\mathrm{Zn}, \mathrm{Cu}$, As and $\mathrm{Cd}$ in the air compared with non-dust days (Guo et al., 2014b). In addition, the dust storms contributed little to the water-soluble fractions of all trace elements.

\subsection{Source identification}

\subsubsection{Correlations between individual elements}

The Pearson correlation coefficients $r$ between each element for both total fraction and water-soluble fraction were examined (Table S4). Moderate significant associations of $\mathrm{Fe}$ with elements $\mathrm{Al}, \mathrm{Mn}$ and $\mathrm{Cr}$ are found to exist both in total and water-soluble fractions with comparable coefficients between 0.40 and 0.68 . Correlations for other trace elements in water-soluble fraction are stronger than in total fraction, suggesting the higher possibilities of common sources for some water-soluble elements. For example, the correlation levels of $\mathrm{Zn}-\mathrm{Cu}, \mathrm{Zn}-\mathrm{Se}, \mathrm{Pb}-\mathrm{Zn}$ and $\mathrm{Pb}-\mathrm{Se}$ are dramatically high for water-soluble fractions $(0.72<r<0.82)$ and moderate for total fractions $(0.25<r<0.52)$, which could be attributed to their common anthropogenic sources of coal-fired power plants and industrial processes based on the suggestion of the spherical morphology and elemental composition of individual metal particles via the TEM examination ( $\mathrm{Li}$ et al., 2014).

\subsubsection{Anthropogenic pollution}

The enrichment factor (EF) for individual trace elements was applied to identify their general crustal and anthropogenic 

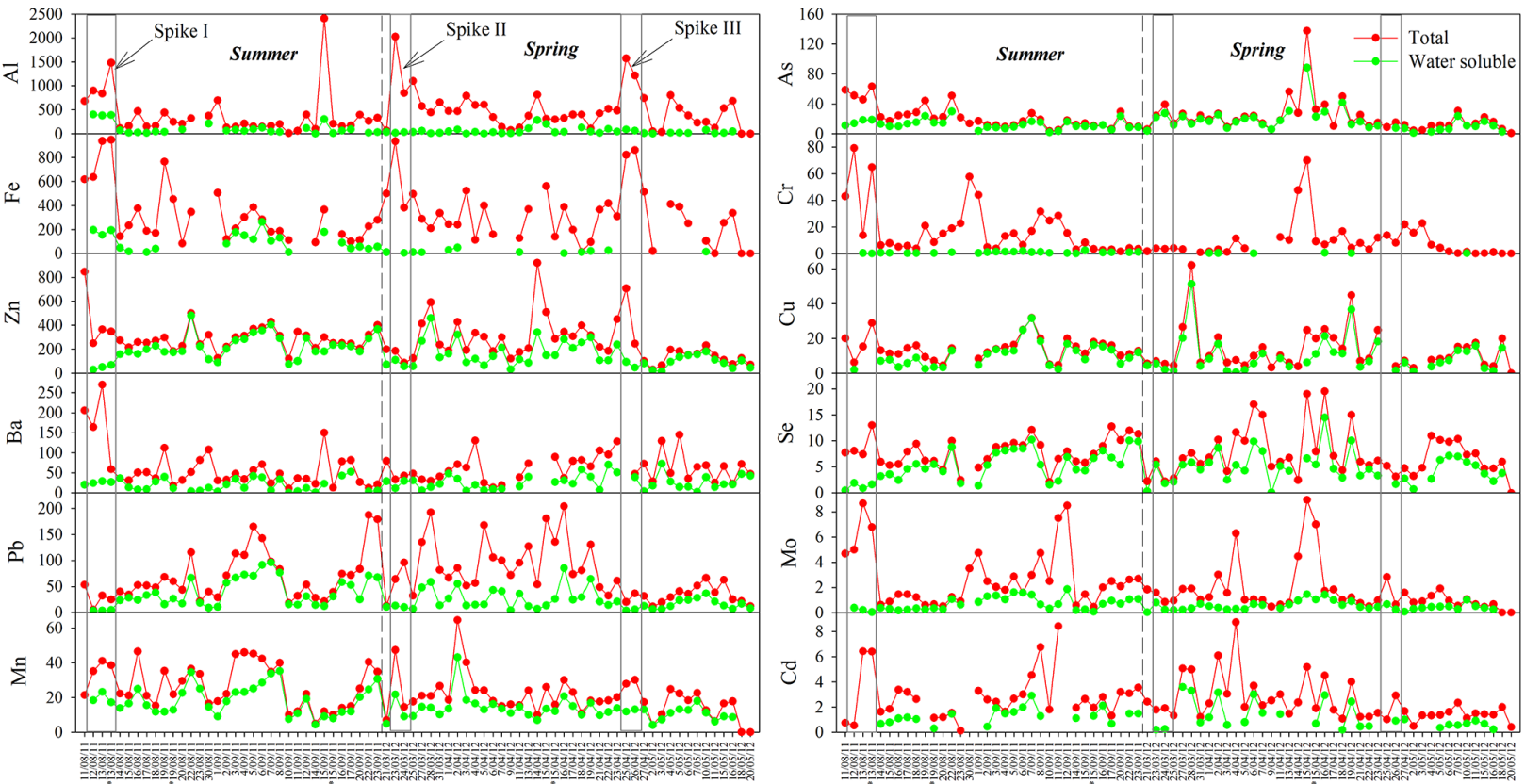

Figure 2. Temporal variations of individual trace element concentrations $\left(\mathrm{ng} \mathrm{m}^{-3}\right)$ in $\mathrm{PM}_{2.5}$ at Mt. Lushan. Boxes indicate the concentration spikes.

sources and evaluate the degree of pollution using the following formula:

$\mathrm{EF}_{i}=\left(X_{i} / X_{R}\right)_{\text {aerosol }} /\left(X_{i}^{\prime} / X_{R}^{\prime}\right)_{\text {crust }}$,

where $\mathrm{EF}_{i}$ is the enrichment factor of element $i ; X_{i}$ and $X_{R}$ are the concentrations of element $i$ and reference element $R$ in aerosol, respectively; $X_{i}^{\prime}$ and $X_{R}^{\prime}$ are the background contents of elements in Chinese soils (Wei et al., 1991); and $\mathrm{Al}$ is selected as the reference element for calculation. Element sources are classified into three groups with the following standard: $\mathrm{EF}<10$ is considered to be a crustal origin without enrichment; $10<\mathrm{EF}<100$ comes from mixed origins (crustal and anthropogenic sources); and EF $>100$ indicates air pollution from an anthropogenic origin. Figure 3 describes the EF values for both the total and water-soluble fractions of each element in a decreasing order. Elements with $\mathrm{EF}>100$, including $\mathrm{Se}, \mathrm{Cd}, \mathrm{Zn}, \mathrm{Pb}, \mathrm{As}$, $\mathrm{Mo}$ and $\mathrm{Cu}$, were found to be highly enriched, ranging from hundreds to tens of thousands in both fractions, indicating the severe anthropogenic pollution of atmospheric trace elements. $\mathrm{Cr}, \mathrm{Ba}$ and $\mathrm{Mn}$ were likely to be from mixed origins because the majority of their EF values fell within 10-100. Fe was predominantly from a crustal origin based on its $\mathrm{EF}<10$. It is worth noting that the water-soluble fractions of most elements (except $\mathrm{Cr}$ and $\mathrm{Fe}$ ) have higher $\mathrm{EF}$ values than the total fractions by approximately 1 order of magnitude.

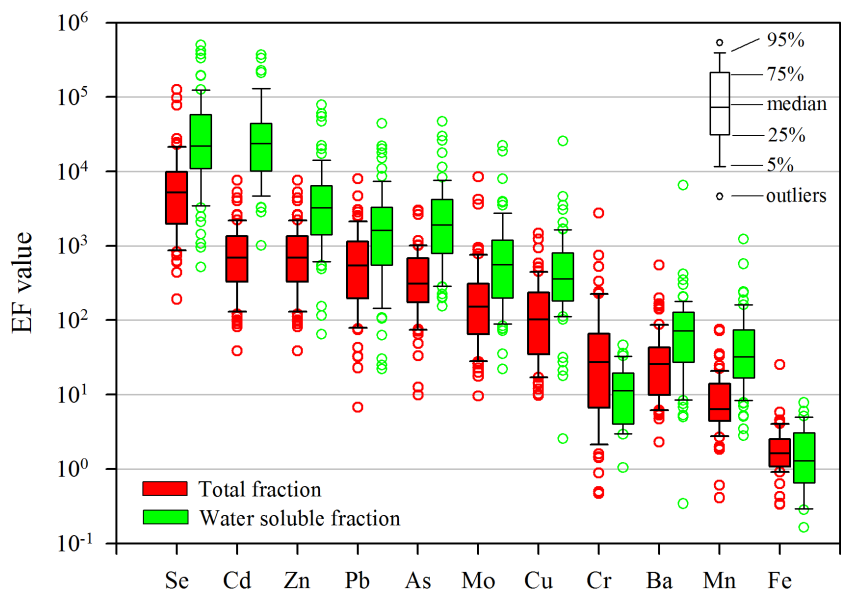

Figure 3. Enrichment factor $(\mathrm{EF})$ values of fine particle trace elements at Mt. Lushan in total and water-soluble fraction.

\subsubsection{Emission source classification}

The principal component analysis (PCA) was performed in detail to classify the main sources of trace elements in $\mathrm{PM}_{2.5}$ at Mt. Lushan. The PCA results for trace elements in total fraction are shown in Fig. 4 with four major components identified.

The first principal component was considered primarily from nonferrous metal mining and metallurgical smelting, accounting for $34.4 \%$ of the total variance with high loadings for $\mathrm{Cr}$, As, and $\mathrm{Ba}$ and considerable loadings for $\mathrm{Zn}$ 
and Mo. Although there were diverse EF values which suggested anthropogenic origins mixed with crustal materials ranging from dozens for $\mathrm{Cr}$ and $\mathrm{Ba}$ to thousands for $\mathrm{As}, \mathrm{Zn}$ and Mo, these total fraction elements still presented considerably moderate correlations. According to the provincial output statistics of nonferrous metals in 2010 (Cheng et al., 2015) and the Overall Planning of Mining Resources of 2008-2015 for Jiangxi and the adjacent Hunan Province, there are abundant nonferrous minerals (such as barite, realgar and sphalerite, etc.) and many large-scale metallurgical industries within and near Jiangxi Province. In addition, high concentrations of $\mathrm{Pb}$ and $\mathrm{Zn}$ in cloud drop residues at Mt. Lushan were suggested as deriving from fine particles contributed by nonferrous smelting in Jiangxi Province ( $\mathrm{Li}$ et al., 2013).

The second principal component that contributed to high loadings for $\mathrm{Pb}, \mathrm{Cu}, \mathrm{Se}, \mathrm{Zn}$ and $\mathrm{Mn}$ was identified as coal combustion. Coal combustion is representatively considered to be the source of most atmospheric trace elements in China. All species in this component except Mn exhibited high EF values, indicating their anthropogenic origins. The semivolatile Se is usually used as a tracer for determining atmospheric sources and even the pathways of coal combustion pollutants, because it is primarily produced in hightemperature combustion and can undergo long-range transport with fine particles after the rapid gas-to-particle conversion (Husain et al., 2004; Wen and Carignan, 2007). Coal combustion is also becoming the major contributor to atmospheric $\mathrm{Pb}$ with the nationwide phase-out of leaded gasoline in China (Xu et al., 2012). The high correlations between Se and the other species in Component 2 clearly indicated the likely sources of coal combustion.

The third component in particular explained most of the $\mathrm{Al}$ and $\mathrm{Fe}$ which are the typical signatures of crustal materials or soils, along with relatively high correlations and low EF values.

Municipal solid waste incineration was regarded as the primary source of fine particle Cd and Mo at Mt. Lushan, explaining $8.4 \%$ of the variance. Both $\mathrm{Cd}$ and Mo had low concentrations but high EF values, with a strong association in total fraction $(r=0.71)$. Jakob et al. (1995) found that $\mathrm{Cd}$ in fly ash of municipal solid waste incinerators could evaporate into the atmosphere completely during heat treatment. The rapid increase in atmospheric $\mathrm{Cd}$ emissions from municipal solid waste incineration in recent years and the unbalanced large emissions in eastern-central and south-eastern China (Tian et al., 2012) were responsible for fine particle $\mathrm{Cd}$ at Mt. Lushan.

\subsection{Potential source region distributions}

Three-day air-mass backward trajectories were calculated to estimate the potential source regions and pathways of air pollutants, making full use of the geographical advantages of the high-altitude observation site and the long-range trans-
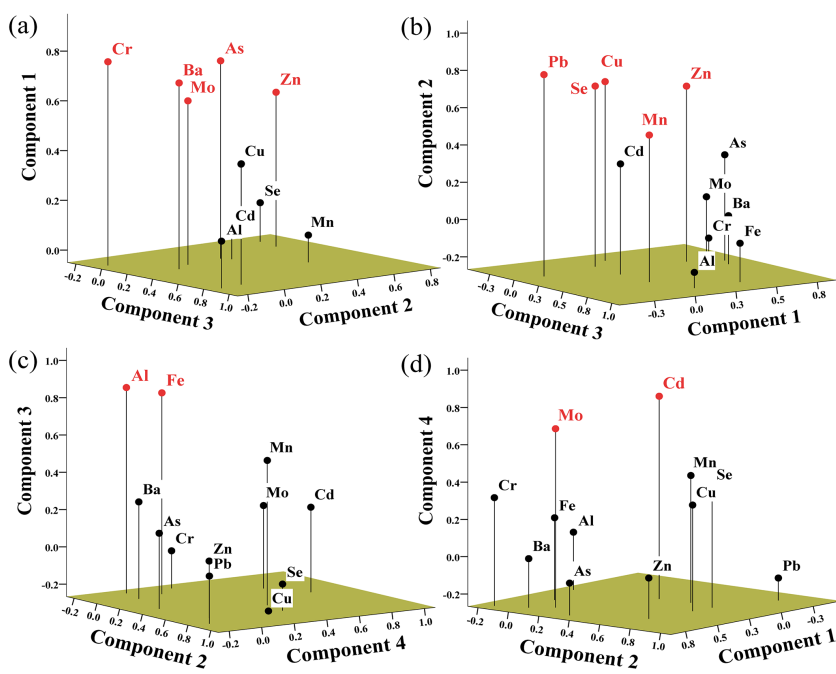

Figure 4. Loadings of (a) Component 1, (b) Component 2, (c) Component 3 and (d) Component 4 for trace elements in total fraction in $\mathrm{PM}_{2.5}$.
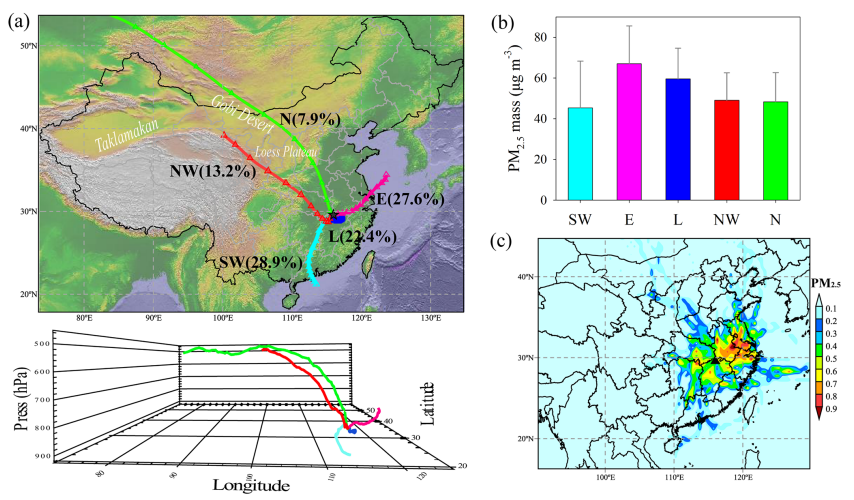

Figure 5. (a) Three-day mean trajectories arriving at Mt. Lushan, (b) averaged $\mathrm{PM}_{2.5}$ concentration of five clusters, and (c) the likely source regions of $\mathrm{PM}_{2.5}$ identified using PSCF plots during the observation period.

port capacity of fine particles. The air masses associated with $\mathrm{PM}_{2.5}$ samples were classified into five clusters (Fig. 5a). The air masses of the Southwest (SW) cluster originated from the South China Sea and passed through the Pearl River delta (PRD), Hunan and Jiangxi Province, with the highest occurrence frequency of $28.9 \%$. Cluster East (E) mainly came from the East China Sea and partly from the Circum-Bohai sea region, traversing the Yangtze River delta (YRD) and Anhui Province at a frequency of $27.6 \%$. Air masses of cluster Local (L) were found to be advancing toward or revolving around Mt. Lushan slowly from ground level within areas covering distances of approximately $200 \mathrm{~km}$ away from the observation site, contributing $22.4 \%$ of the occurrence frequency. Clusters Northwest (NW) and North (N) both went through the China Loess Plateau and accounted for 13.2 and 
$7.9 \%$ of the occurrence frequency, respectively. The primary difference was that the former mainly originated from Taklimakan and the Gobi Desert, whereas the latter was from remote Siberia and Mongolia, with a much higher wind speed.

Figure $5 \mathrm{~b}$ shows the averaged $\mathrm{PM}_{2.5}$ concentration of different clusters. Cluster E exhibited the highest $\mathrm{PM}_{2.5}$ concentration of $67.0 \mu \mathrm{g} \mathrm{m}^{-3}$, followed by cluster L $\left(59.6 \mu \mathrm{g} \mathrm{m}^{-3}\right)$ and the similar clusters NW and N, whereas cluster SW had the lowest concentration $\left(45.3 \mu \mathrm{g} \mathrm{m}^{-3}\right)$. The order of $\mathrm{PM}_{2.5}$ concentration seemed to be consistent with the PSCF result (Fig. 5c) which integrated $\mathrm{PM}_{2.5}$ concentration with air-mass occurrence frequency. As shown in Fig. 5c, the YRD and southern Anhui Province were the most likely source regions of $\mathrm{PM}_{2.5}$ at Mt. Lushan. These economically developed regions exhibit massive energy consumption and industrial production, becoming important anthropogenic source regions in eastern China. Local Jiangxi, the neighbouring southern Anhui and eastern Hunan were also significant $\mathrm{PM}_{2.5}$ source regions, where many nonferrous metal smelting industries are widely distributed. However, the contributions to $\mathrm{PM}_{2.5}$ at Mt. Lushan by long-range transport of air masses from northern China (Inner Mongolia and the Loess Plateau) were far fewer than from eastern China and local regions, suggesting nearly negligible impacts of mineral dusts or soil transport on fine particle mass concentration at Mt. Lushan compared with regional anthropogenic pollution. In addition, the $\mathrm{PM}_{2.5}$ concentration in five clusters or different source regions were highly dependent on the inorganic ions, especially the secondary ions (Li et al., 2014). Interestingly, the PRD contributed far fewer concentrations to fine particles in spite of its high occurrence frequency, probably due to particle scavenging by frequent rainfall during the Asian summer monsoon.

Figure 6a-1 illustrates the distinctive potential source region distributions for individual elements in fine particles at Mt. Lushan. Crustal elements $\mathrm{Al}$ and $\mathrm{Fe}$ exhibited similar source region distributions (Fig. 6a and b). The highest PSCF values in northern China including the Loess Plateau, Henan and eastern Hubei Province indicated that these areas were very important source regions and pathways for fine particle $\mathrm{Al}$ and $\mathrm{Fe}$, with vast contributions of long-range transport of mineral dusts or soils. The PRD and eastern Hunan Province were likely to be other important source regions for $\mathrm{Al}$ and $\mathrm{Fe}$, probably due to the influence of mining activities, whereas the YRD in eastern China and the local Jiangxi Province made much lower contributions.

Fine particle As (Fig. 6c) had an almost parallel pattern of source region distribution with $\mathrm{Fe}$, except the discordance that the PRD, eastern Guangxi, Hunan and Jiangxi Province were identified as the most important source regions and pathways, attributable to the emissions of the nonferrous metal mining and smelting industries. Northern China also tended to be an important potential source region, suggesting the possible contribution of natural sources for As. Similarly to As, the PRD, Hunan and Jiangxi Province, as well as northern China, were also potential source regions for fine particle Mn (Fig. 6d). However, the YRD area was characterised by extremely high PSCF values for Mn, indicating an important anthropogenic source region.

Fine particle $\mathrm{Pb}, \mathrm{Zn}, \mathrm{Cu}$ and $\mathrm{Se}$ (Fig. 6e-h), which were identified primarily from coal combustion by the PCA analysis, had similar source region distributions with some discrepancies, generally coinciding with the geographical distribution of coal-fired power plants in China which were aggregated within coastal areas such as the YRD, the PRD and Shandong Province (Fig. S5a). The YRD area including Jiangsu, Zhejing and southern Anhui Province was an especially pronounced source region of $\mathrm{Pb}, \mathrm{Zn}, \mathrm{Cu}$ and $\mathrm{Se}$ at Mt. Lushan. The significantly high PSCF values in the YRD region were attributable to the large coal consumption by intensive power plants in Jiangsu, Zhejiang and even Shandong Province, and to the differences in trace element contents in raw coal such as high Se contents in Anhui Province, both of which made great contributions to emissions of atmospheric trace elements (Tian et al., 2014). Meanwhile, the PRD, Hunan and the local area of Jiangxi Province also played a remarkable role in source region distributions of $\mathrm{Zn}, \mathrm{Cu}$ and Se at Mt. Lushan, for which coal-fired power plants and nonferrous metal smelting industries in these areas were primarily responsible. Unexpectedly, northern China rather than the PRD area was also identified as a potential source region of fine particle $\mathrm{Pb}$, possibly attributed to the partial contributions of long-range transport of mineral dusts.

As shown in Fig. 6i and $j$, the YRD, the PRD, eastern $\mathrm{Hu}-$ nan and western Jiangxi were identified as the common likely source regions and pathways for fine particle $\mathrm{Cd}$ and $\mathrm{Mo}$ at Mt. Lushan. The identified source regions corresponded very well to the uneven regional distribution of municipal solid waste (MSW) incineration plants in China (Fig. S5b), with $183.5,175.1$ and $146.6 \mathrm{~kg}$ of atmospheric Cd emitted by MSW incineration from Jiangsu, Zhejiang and Guangdong, respectively, the top three largest emitting provinces in 2010 (Tian et al., 2012). Figure 6k shows an apparently more homogeneous source region distribution for $\mathrm{Ba}$, with the PRD and areas surrounding Mt. Lushan as potential source regions which have a high natural background content of barite. On the contrary, few potential source regions were identified for $\mathrm{Cr}$ (Fig. 61) besides the PRD, parts of Hunan Province and a small region in central Zhejiang with low PSCF values.

It should be noted that the potential source region distributions for trace elements at Mt. Lushan were very different with $\mathrm{PM}_{2.5}$. The YRD, the PRD and Hunan Province were likely to be the major source regions for most anthropogenic elements (except $\mathrm{Cu}$ within eastern Jiangxi), and northern China was likely for crustal elements ( $\mathrm{Al}$ and $\mathrm{Fe}$ ). However, the contribution probabilities of areas near Mt. Lushan for most elements were obviously lower than other source regions. This result revealed that long-range transport and regional anthropogenic sources, rather than local sources, made much more significant contributions to fine particle 
(a)

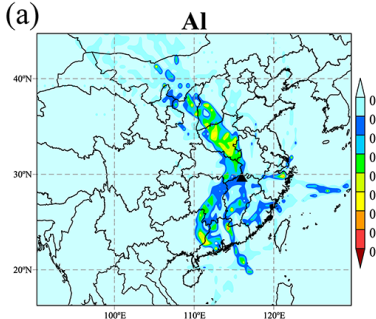

(e)

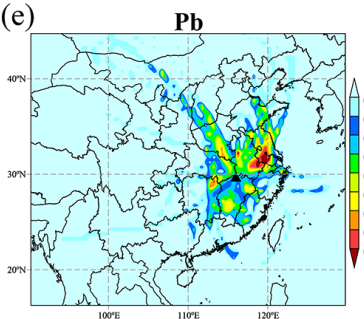

(i)

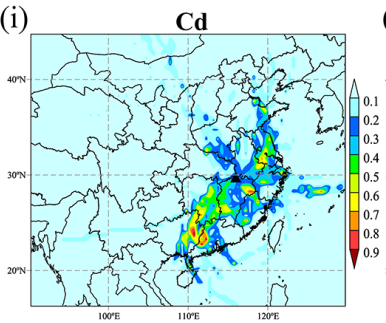

(b)

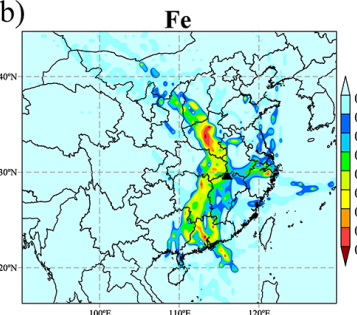

(f)

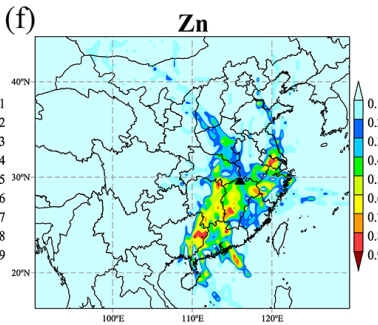

(j) (c)

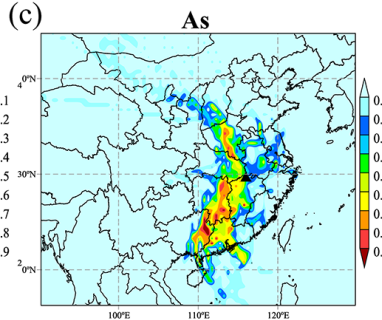

(g)

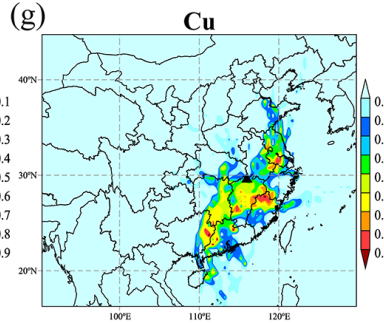

Ba

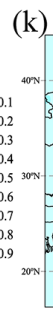

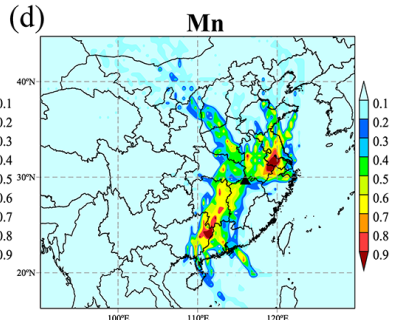

(h)

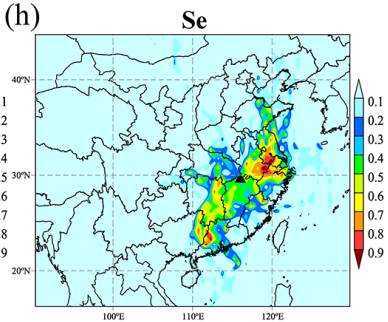

(1)

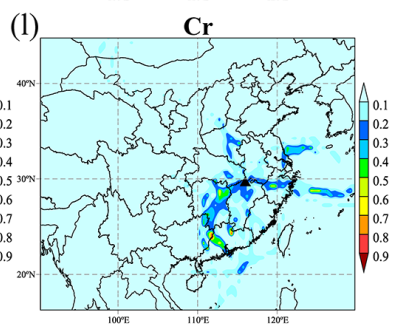

Figure 6. Likely source regions of individual elements in $\mathrm{PM}_{2.5}$ at Mt. Lushan, identified using PSCF plots. Note the criteria are the 75 th percentile for $\mathrm{Al}$ and the mean concentration for others.

trace elements at Mt. Lushan, which could be ascribed to the different types and quantities of emissions as well as the protection policies for Mt. Lushan and its adjacent Poyang Lake.

In addition, the order of mass concentration of individual trace elements for five air-mass clusters ending at Mt. Lushan (Fig. S6) was in accordance with the distributions of likely source regions identified by PSCF values, further suggesting greater contributions by regional sources and long-range transport to fine particle trace elements at Mt. Lushan. For example, clusters $\mathrm{N}$ and NW contributed to the highest concentration for crustal $\mathrm{Al}$ and $\mathrm{Fe}$ and anthropogenic $\mathrm{Zn}$ and As, followed by the highest clusters SW and E and the lowest cluster L; exceptionally, cluster L made the highest contribution to the combustion element $\mathrm{Cu}$.

\subsection{Trace element solubility}

\subsubsection{Comparison of individual element solubility}

In this study, element solubility is calculated as the percentage of water-soluble concentration of an element divided by its total concentration. Figure 7 compares the average water solubility of individual elements in $\mathrm{PM}_{2.5}$ at Mt. Lushan with other sites in decreasing order. The most soluble elements were $\mathrm{As}, \mathrm{Mn}, \mathrm{Cu}, \mathrm{Zn}$ and $\mathrm{Se}$ with a solubility reaching up to $60-70 \%$, followed by $\mathrm{Cd}, \mathrm{Pb}, \mathrm{Ba}$ and Mo with moderate solubility, approximately $40-50 \%$, whereas the least sol-

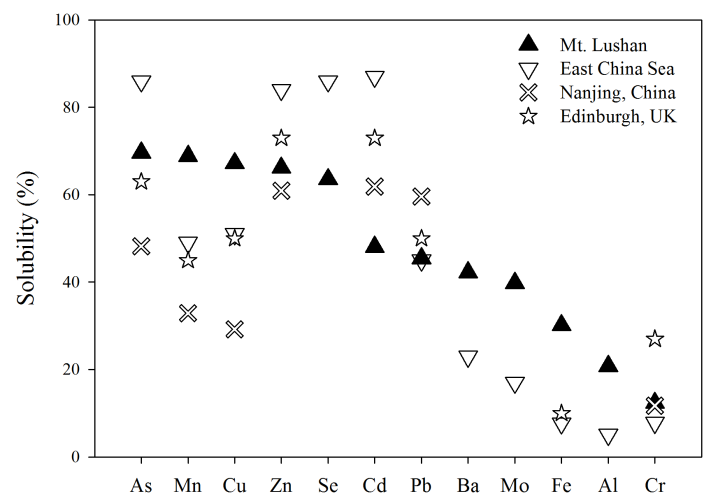

Figure 7. Comparison of element solubility for aerosol at Mt. Lushan $\left(\mathrm{PM}_{2.5}\right.$, this study), the East China Sea (TSP, NE $\mathrm{NAD}$ group, Hsu et al., 2010), Nanjing, China ( $\mathrm{PM}_{2.5}$, Hu et al., 2012), and Edinburgh, UK $\left(\mathrm{PM}_{2.5}\right.$, urban background site, Heal et al., 2005).

uble elements were $\mathrm{Fe}, \mathrm{Al}$ and $\mathrm{Cr}$ with a solubility less than $30 \%$. Compared with TSP over the East China Sea (Hsu et al., 2010), some elements ( $\mathrm{Mn}, \mathrm{Cu}, \mathrm{Ba}, \mathrm{Mo}, \mathrm{Fe}$ and $\mathrm{Al}$ ) were significantly highly soluble in $\mathrm{PM}_{2.5}$ at $\mathrm{Mt}$. Lushan, whereas other species (As, Zn, Se and Cd) showed the opposite with the exception of comparable $\mathrm{Pb}$ and $\mathrm{Cr}$. Similarly, compared with the $\mathrm{PM}_{2.5}$ at Edinburgh, UK (Heal et al., 2005), the 


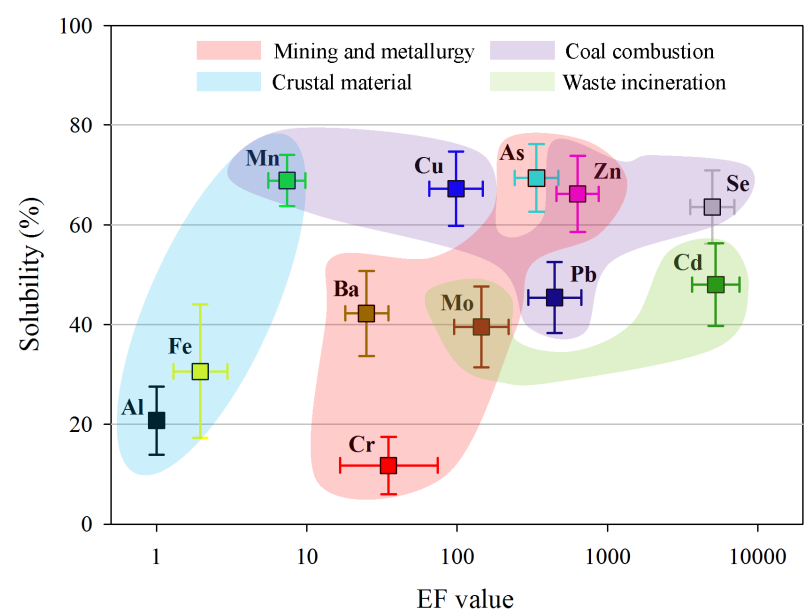

Figure 8. Scatter plot of aerosol element solubility versus the logarithmic EF value, computed with the geometric mean in the $99 \%$ confidence interval. Coloured shade areas represent different sources classified by EF value and PCA analysis.

elements $\mathrm{Mn}, \mathrm{Cu}$ and $\mathrm{Fe}$ exhibited higher water solubility, whereas the elements $\mathrm{As}, \mathrm{Zn}$ and $\mathrm{Pb}$ were comparable, and the elements $\mathrm{Cd}$ and $\mathrm{Cr}$ were lower at Mt. Lushan. A large gap in anthropogenic elements (As, $\mathrm{Mn}, \mathrm{Cu}$ and $\mathrm{Pb}$ ) between Mt. Lushan and Nanjing (Hu et al., 2012) was also observed. Experimental conditions (compared in the Supplement, Table S5) such as digestion methods or analysis instruments may result in some solubility discrepancies at different sites, but they are far from the determinant.

\subsubsection{Effect of emission sources on element solubility}

Element solubility is associated with four major emission sources identified by EF value and PCA analysis and displayed in Fig. 8. Crustal elements with mean EF $<10$ had low average solubility $(<30 \%)$ besides the highly dissolved $\mathrm{Mn}$ that was possibly impacted by a combustion source; the solubility of elements related to mining and metallurgy varied between $<10$ and $70 \%$, with a $10-1000$ range in EF value; coal combustion elements characterised by high EF values over 100 exhibited a high solubility of approximately $45-75 \%$, attributable to the combustion process during which oxidisable elements in coal are mostly altered to easily soluble species (Quispe et al., 2012); elements produced by waste incineration were also highly soluble (40$50 \%$ ) coupled with $\mathrm{EF}>100$. The roughly increasing tendency of solubility along with the EF value suggested that element solubility was closely related to the emission sources, likely indicating that crustal elements with low EF values often showed low solubility, whereas polluted elements featuring high EF values were usually highly soluble. This result coincides well with the conclusion that the dissolvable portion of aerosol elements is controlled by their dominant crustal or anthropogenic origins (Hsu et al., 2005). However, there are also some exceptions that could not be explained by emission sources. For instance, the low solubility of atmospheric $\mathrm{Cr}$ at Mt. Lushan could probably be ascribed to the stable crystalline structure in minerals such as chromite, with the reduced $\mathrm{Cr}$ (III) being the dominant species in ambient fine particles (Werner et al., 2007). Figure S7 further shows a hyperbolic or negative logarithmic relationship between element concentration and the solubility for and only for $\mathrm{Al}, \mathrm{Fe}, \mathrm{Cr}$ and $\mathrm{Mn}$, similar to many inverse relationships for aerosol $\mathrm{Fe}, \mathrm{Al}$ and other species reviewed by Schulz et al. (2012), indicating the unneglected effect of total concentration on crustal trace element solubility rather than anthropogenic elements. Thus, trace element solubility may be initially determined by emission sources with various interferences.

\subsubsection{Source region contributions to element solubility}

Figure 9 illustrates the potential source regions for individual element solubility in $\mathrm{PM}_{2.5}$ at Mt. Lushan with the expanding application of PSCF analysis to evaluate the local and regional contributions. It can be seen that almost all of the elements had quite different solubility distributions with their total concentrations, characterised by the highest PSCF values for element solubility in local Jiangxi and the YRD region followed by lower PSCF values in parts of the PRD region and Hunan Province.

In this study, we used fine particle Fe for detailed explanation because there are many investigations on the solubility of aerosol $\mathrm{Fe}$, which plays a critical role in the global iron cycle among terrestrial dust, the atmosphere and the ocean, as well as in the effects on climate (Jickells et al., 2005). As shown in Fig. 9a, northern China, identified as the major source region for crustal $\mathrm{Fe}$, made little contribution to its solubility. The significantly low solubility of fine particle Fe in northern China, much lower than the PSCF criteria value, was consistent with the very low soluble Fe (solubility less than $2 \%$ ) from desert dusts or soils (Baker et al., 2006; Jickells et al., 2005). The experiment performed by Mackie et al. (2006) suggests that the amount of readily released $\mathrm{Fe}$ does not increase after the uplift and abrasion of soils in areas with little atmospheric pollution; thus, the low solubility of the Fe from northern China could be attributed to the initial absence of dissolved $\mathrm{Fe}$ in dusts or soils derived from the Gobi Desert or Loess Plateau. On the contrary, the relatively much higher PSCF values for Fe in the local Jiangxi, southern Anhui and the YRD indicated greater contributions of anthropogenic pollution in these regions to the solubility of fine particle $\mathrm{Fe}$ at Mt. Lushan, because the high solubility of $\mathrm{Fe}$ in the YRD and Anhui Province was just in accordance with the large amounts of anthropogenic emissions of $\mathrm{SO}_{2}$ and $\mathrm{NO}_{x}$ in these regions (Zhang et al., 2009), which could significantly promote the dissolution of aerosol Fe acting as acid precursors (Schulz et al., 2012; Solmon et al., 2009). A significant correlation (0.629) of iron solubility and sulfate 
(a)

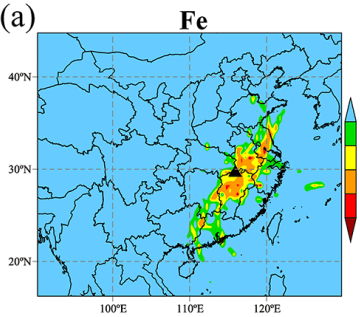

(e)

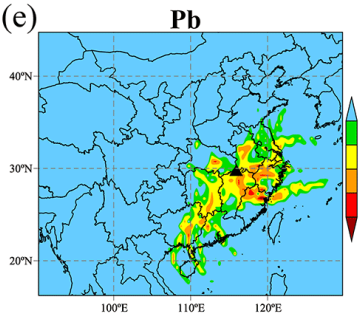

(i)

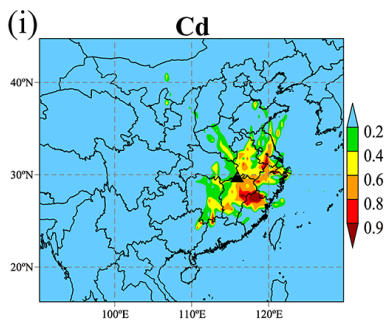

(b)

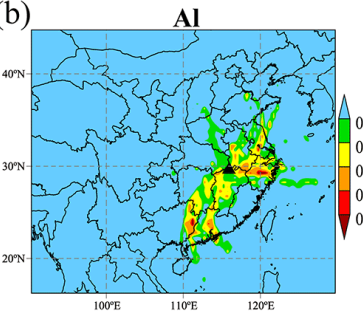

(f)

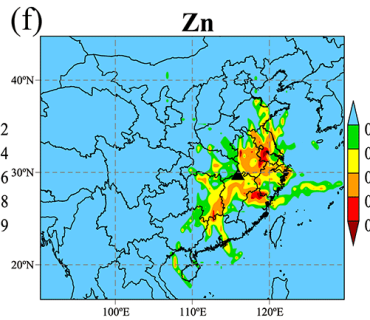

Mo

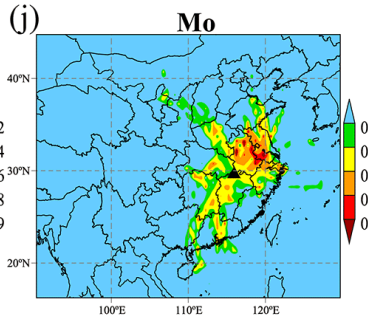

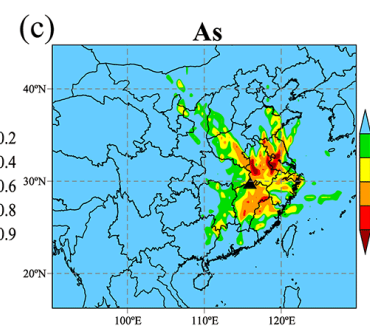

(g)

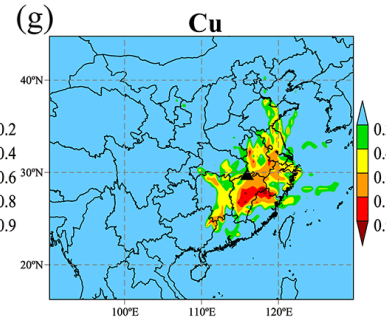

Ba

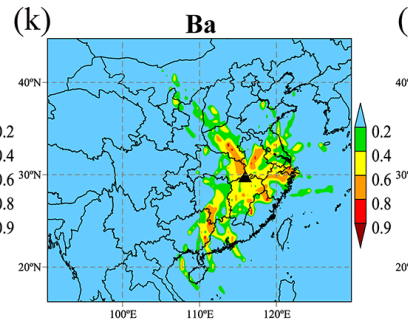

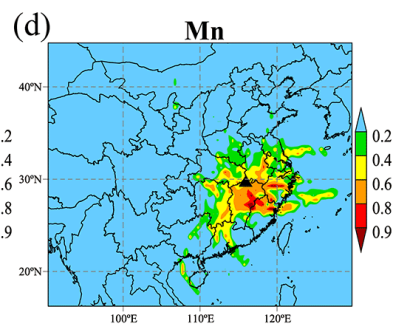

(h)

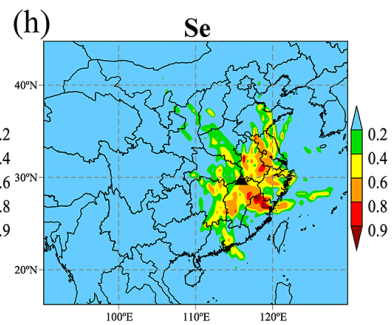

(1)

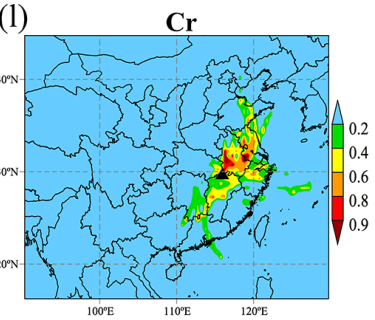

Figure 9. Solubility distributions in likely source regions for individual elements in $\mathrm{PM}_{2.5}$ at Mt. Lushan, identified by PSCF with the mean solubility values as criteria.

concentration in our fine particle samples was further verified, similar to the correspondence of high iron solubility to the sulfur content in ambient fine particles observed by Oakes et al. (2012). Moreover, the outstanding enhancement of fine particle Fe solubility in local regions close to Mt. Lushan was principally recognised to be an effect of cloud processing, an important atmospheric process controlling Fe dissolution in aerosols (discussed in Sect. 3.4.4). The regional distributions for the solubility of crustal $\mathrm{Al}$ was similar to $\mathrm{Fe}$, except for the lower PSCF values near Mt. Lushan (Fig. 9b).

Anhui, Jiangsu and Jiangxi Province were identified as the most important contributors to the high solubility of fine particle As at Mt. Lushan (Fig. 9c), ascribed to the large number of atmospheric As emissions from anthropogenic sources (approximately 200 ton in 2010) in these provinces (Cheng et al., 2015); in contrast, few contributions were made to As solubility by the PRD and Hunan Province where the highest As concentrations were provided. For the elements from coal combustion (including $\mathrm{Mn}, \mathrm{Pb}, \mathrm{Zn}, \mathrm{Cu}$ and $\mathrm{Se}$, Fig. 9d-h) and MSW incineration (including $\mathrm{Cd}$ and $\mathrm{Mo}$, Fig. 9i and j), the highest contributions of element solubility were uniformly focused within Jiangxi Province, the YRD and parts of Fujian Province, generally coinciding with their significantly high concentrations emitted from anthropogenic sources in eastern China. The solubility pattern for $\mathrm{Ba}$ (Fig. 9k) was rather similar to its concentration distribu- tion, whereas the pattern of high solubility for $\mathrm{Cr}$ in Anhui Province (Fig. 91) was very different to the concentration pattern.

It can be concluded that the solubility of fine particle trace elements from local and regional source regions was much higher than that by long-range transport from south-western China and northern China. The high contributions for particle element solubility in the YRD region should be attributed to the serious air pollution. However, on account of the relatively less air pollution released from local sources, the frequent cloud processing was considered as the significant contributor to the high solubility of trace elements in local regions near Mt. Lushan.

Additionally, the statistics on the solubility of individual fine particle elements at Mt. Lushan for five air-mass categories are shown in Fig. S8. In general, the fine particle elements derived from cluster $\mathrm{L}$ exhibited the highest solubility whether for crustal or anthropogenic elements, closely followed by cluster E; elements from cluster SW showed moderate solubility, ascribed to the wash-out of soluble constituents by frequent rainfall in summer monsoon; elements from cluster $\mathrm{NW}$ and $\mathrm{N}$ were the least soluble, primarily impacted by crustal materials from northern China. It was demonstrated that the statistical results for most elements fairly agreed with the solubility distributions identified by PSCF analysis. 


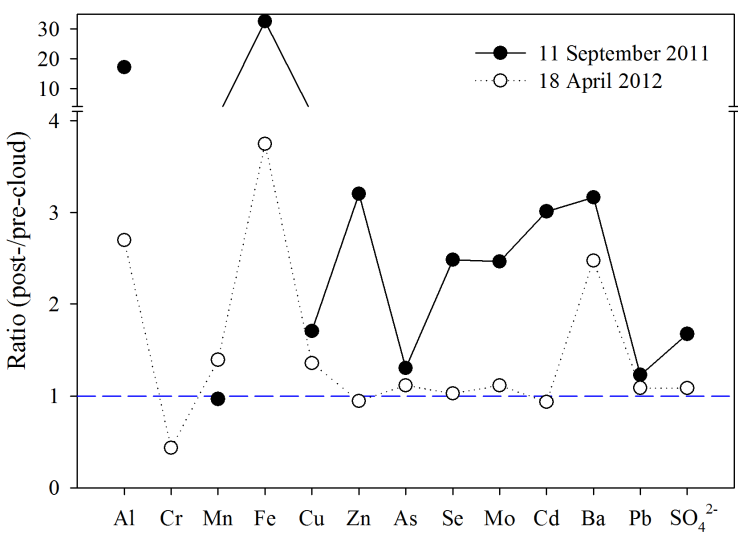

Figure 10. The increments of trace element solubility and sulfate concentrations by cloud processing. It is plotted as the ratios of postto pre-cloud solubility or concentrations. Ratio $>1$ (blue dashed line) indicates an increase in solubility or concentration.

\subsubsection{Evolution of element solubility during cloud processing}

Cloud processing might be of great importance in affecting aerosol dissolution at Mt. Lushan where frequent cloud events occurred. To determine the evolution of element solubility during cloud processing, cloud events were selected with the following conditions: (1) non-raining cloud to avoid scavenging of particles by precipitation, (2) short duration and time interval of cloud processing and particle sampling to minimise the interference of external aerosols, and (3) identical air-mass trajectory of the cloud and particles with low wind speed to ensure consistent origins of the air masses. Figure 10 and Table S6 show the alteration of individual element solubility in fine particles after two selected cloud events on 11 September 2011 and on 18 April 2012.

It was evident that after cloud processing on 11 September 2011, most fine particle elements exhibited a drastic increase in solubility. For instance, post-cloud particle Al became much more soluble compared with the pre-cloud particle, with solubility changing from 1.7 to $28.7 \%$. Other elements, such as $\mathrm{Cu}, \mathrm{Zn}, \mathrm{As}$, Se, $\mathrm{Cd}$ and $\mathrm{Ba}$, also showed an approximately 1- to 2-fold increase in solubility. The cloud processing on 18 April 2012 also brought about a significantly large number of solubility increments for the crustal elements $\mathrm{Al}$ and $\mathrm{Fe}$. The fewer increments for anthropogenic elements such as $\mathrm{Cu}, \mathrm{As}, \mathrm{Se}$ and $\mathrm{Pb}$ should be due to their already higher solubility in pre-cloud particles (Table S6) which might have undergone intensive cloud cycles during the prolonged residence time in the air. Generally, the evidently higher solubility for the post-cloud trace elements after the two cloud events, exceeding their overall average solubility, corroborated the remarkable dissolution efficiencies of aerosol elements by cloud processing at Mt. Lushan.
Interestingly, the increase in aerosol element solubility after the occurrence of cloud processing was coupled with the elevation of aerosol sulfate concentration as shown in Fig. 10 and Table S6. For example, post-cloud sulfate particles $(4 \mathrm{~h})$ exhibited a sharp elevation of $10 \mu \mathrm{g} \mathrm{m}^{-3}$ after the cloud processing ( $3 \mathrm{~h}$ ) on 11 September 2011. Based on the very short intervals between cloud events and post-cloud particle sampling, the increased sulfate particles were most likely contributed by cloud water sulfate, which could be generated by the rapid atmospheric aqueous-phase oxidation of S(IV) with a rate greater than $100 \% \mathrm{~h}^{-1}$ (Seinfeld and Pandis, 2012), much quicker than the gas-phase oxidation of $\mathrm{SO}_{2}$ with a rate of approximately $1 \% \mathrm{~h}^{-1}$ (Newman, 1981). In addition, the higher sulfate concentrations in cloud water and postcloud particles on 11 September $2011\left(41.70 \mathrm{mg} \mathrm{L}^{-1}\right.$ and $24.72 \mu \mathrm{g} \mathrm{m}^{-3}$, respectively) from cluster E compared with those on 18 April $2012\left(26.78 \mathrm{mg} \mathrm{L}^{-1}\right.$ and $17.34 \mu \mathrm{g} \mathrm{m}^{-3}$, respectively) from cluster $\mathrm{L}$ were likely to be associated with the larger amount of anthropogenic $\mathrm{SO}_{2}$ gases from the YRD in eastern China because acidic substances, such as sulfate formed by their precursor gases (e.g. $\mathrm{SO}_{2}$ ), are prone to exist in fine particles and lead to acidification of aerosols (Ren et al., 2011), and the $\mathrm{pH}$ of cloud droplets modified by these dissolved acidic substances in particles could in turn influence the dissolution of aerosol trace elements (Deguillaume et al., 2005). As a consequence, the enhancement of trace element solubility during cloud processing was likely dependent on the corresponding heterogeneous formation of sulfate.

To further understand the effect of cloud processing on aerosol element dissolution, individual cloud droplet residues were collected during the two cloud events, and the micro-morphology and composition of metal particles were examined by TEM-EDS analysis. Representative TEM images and the EDS spectra of major metal particles are shown in Fig. 11. Plenty of Pb-rich, Fe-rich and fly ash particles were observed to be the dominating metal particles in the two cloud events, consistent with the major types of metalassociated particles ( $\mathrm{Pb}$-rich, fly ash, $\mathrm{Fe}$-rich and $\mathrm{Zn}$-rich) in cloud droplets at Mt. Lushan (Li et al., 2013). Almost all of the metal particles were found to be internally mixed within S-rich cloud residues with the encapsulation of cloud water and presented a nearly spherical shape or aggregation, suggesting the likely sources to be high-temperature coal combustion by coal-fired power plants and industries, during which industrial gases containing abundant $\mathrm{SO}_{2}$ and metals were released, followed by the generation of metal-sulfate particles (Gieré et al., 2006).

Figure 11 also demonstrates the small diameters of the metal particles in cloud residues much smaller than $1 \mu \mathrm{m}$, especially for the aggregation of spherical $\mathrm{Fe}$ nanoparticles embedded in aged S-rich residues (Fig. 11c). The unique, large specific surface of nano-sized Fe particles is able to effect a higher absorption intensity and more complicated surface chemistry during cloud processing, generating greater quantities of surface complexes with acidic anions such as 

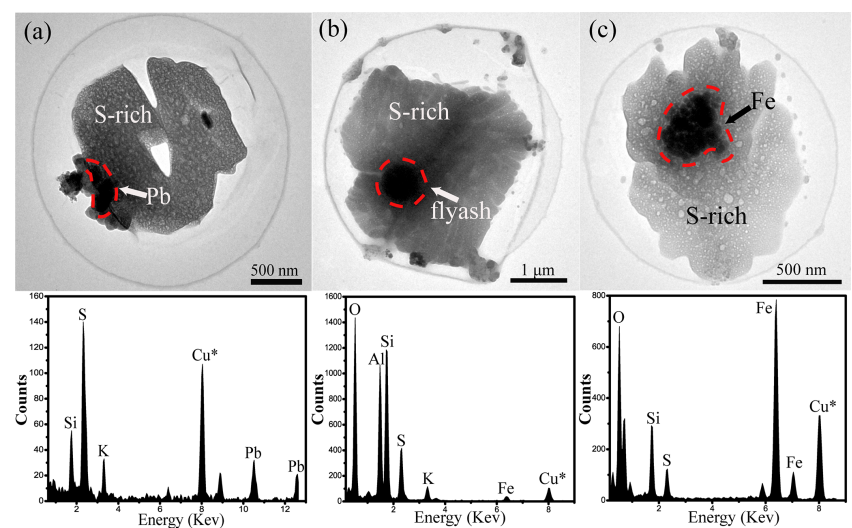

Figure 11. Typical TEM images and corresponding EDS spectra of metal particles embedded in individual S-rich cloud residues collected during cloud events. (a) $\mathrm{Pb}-\mathrm{S}$. (b) Fly ash-S. (c) Fe-S. The dotted red circles indicate the examined area of EDS. $\mathrm{Cu}^{*}$ signals the result from the copper TEM grid.

sulfate, and improving the dissolution rates of iron particles (Rubasinghege et al., 2010). Shi et al. (2009) suggested that the variations in $\mathrm{pH}$ during cloud processing would induce the formation of amorphous $\mathrm{Fe}$ nanoparticles and an increase in iron solubility (reactivity) in Saharan dusts. More importantly, the solubilisation of aerosol elements caused by the change in particle morphology during cloud processing is irreversible (Deguillaume et al., 2005). Finally, along with the dissipating of cloud water in droplets, the Fe nanoparticles and sulfate residues remain in post-cloud particles, resulting in an attractive enhancement of Fe solubility. Therefore, we can conclude that irreversible changes or alterations of particle morphology such as specific surface area, which may result from the acidification and heterogeneous reactions during cloud processing, should be the critical factor for the significant enhancement of solubility not only for $\mathrm{Fe}$, but also for many other trace elements in cloud-processed fine particles.

\section{Conclusions}

The characteristics of fine particle trace elements at the summit of a mountain in southern China were investigated. The $\mathrm{PM}_{2.5}$ concentration $\left(55.2 \pm 20.1 \mu \mathrm{g} \mathrm{m}^{-3}\right)$ was twice the WHO guideline but much lower than that at urban sites, with little seasonal variation. The total fractions of $\mathrm{Al}$ and $\mathrm{Fe}$ and the water-soluble fraction of $\mathrm{Zn}$ were the dominant elements. Similar temporal variations between the total and water-soluble fractions for all species along with several spikes contributed by dust storms for $\mathrm{Al}$ and $\mathrm{Fe}$ were observed. The enrichment factor analysis showed notable air pollution to aerosol trace elements at Mt. Lushan, especially to the water-soluble fractions. Nonferrous metal mining and smelting, coal combustion, crustal materials and municipal solid waste incineration were further classified as the major emission sources, which could initially determine the trace element solubility with interferences such as total concentrations. The YRD including Jiangsu, Zhejiang and parts of Anhui Province were indicated as the most important source regions of $\mathrm{PM}_{2.5}$ by trajectory cluster analysis and PSCF results, which was discrepant with the source distributions for individual trace elements. The YRD, the PRD, eastern Hunan and western Jiangxi were identified as the primary source regions and transport pathways for combustion-related elements ( $\mathrm{Mn}, \mathrm{Pb}, \mathrm{Zn}, \mathrm{Cu}, \mathrm{Se}, \mathrm{Cd}$ and $\mathrm{Mo}$ ) which were emitted by regional coal-fired power plants and municipal solid waste incineration, whereas the long-range transport of mineral dusts from northern China was the major contributor to crustal $\mathrm{Al}$ and $\mathrm{Fe}$. Interestingly, local regions contributed relatively less to trace element concentrations. However, the YRD region and Jiangxi Province were likely to make the greatest contributions to element solubility rather than longrange transport from northern or southern China. Significant enhancement in trace element solubility and the corresponding increase in aerosol sulfate were observed during two selected cloud events. TEM-EDS analysis of cloud residues showed the metal particles were mostly mixed with sulfate. It was concluded that the irreversible alteration of particle morphology by heterogeneous reactions or acidification with sulfate during cloud processing could crucially increase trace element solubility.

This study highlighted the contributions of regional anthropogenic pollution and cloud processing to trace element solubility of $\mathrm{PM}_{2.5}$ at Mt. Lushan. We expect that fine particles would undergo several cloud-processing cycles during long-range transport with massive clouds covering the surface of the earth, which can promote aerosol element dissolution and increase health and ecological risks.

\section{The Supplement related to this article is available online at doi:10.5194/acp-15-8987-2015-supplement.}

Acknowledgements. This research was funded by the National Natural Science Foundation of China (21177073 and 41075092) and the Shandong Provincial Science Fund for Distinguished Young Scholars, China (JQ201413). We acknowledge the NOAA Air Resources Laboratory (ARL) for provision of the HYSPLIT trajectory model. We are grateful to all the staff of Lushan Mountain Meteorological Station for offering the observation platform and their assistance during the field campaigns. Thanks are also due to Taixing Yue at the Environmental Monitoring Central Station of Shandong Province for the help in the ICP-MS measurements.

Edited by: J. Z. Ma 


\section{References}

Baker, A. R., Jickells, T. D., Witt, M., and Linge, K. L.: Trends in the solubility of iron, aluminium, manganese and phosphorus in aerosol collected over the Atlantic Ocean, March Chem., 98, 43-58, doi:10.1016/j.marchem.2005.06.004, 2006.

Cakmak, S., Dales, R., Kauri, L. M., Mahmud, M., Van Ryswyk, K., Vanos, J., Liu, L., Kumarathasan, P., Thomson, E., Vincent, R., and Weichenthal, S.: Metal composition of fine particulate air pollution and acute changes in cardiorespiratory physiology, Environ. Pollut., 189, 208-214, doi:10.1016/j.envpol.2014.03.004, 2014.

Cao, J., Xu, H., Xu, Q., Chen, B., and Kan, H.: Fine particulate matter constituents and cardiopulmonary mortality in a heavily polluted Chinese city, Environ. Health Perspect., 120, 373-378, doi:10.1289/ehp.1103671, 2012.

Charrier, J. G., McFall, A. S., Richards-Henderson, N. K., and Anastasio, C.: Hydrogen peroxide formation in a surrogate lung fluid by transition metals and quinones present in particulate matter, Environ. Sci. Technol., 48, 7010-7017, doi:10.1021/es501011w, 2014.

Chen, J., Tan, M., Li, Y., Zheng, J., Zhang, Y., Shan, Z., Zhang, G., and Li, Y.: Characteristics of trace elements and lead isotope ratios in $\mathrm{PM}(2.5)$ from four sites in Shanghai, J. Hazard. Mater., 156, 36-43, doi:10.1016/j.jhazmat.2007.11.122, 2008.

Chen, Y., Ebenstein, A., Greenstone, M., and Li, H.: Evidence on the impact of sustained exposure to air pollution on life expectancy from China's Huai River policy, Proc. Natl. Acad. Sci. USA, 110, 12936-12941, 2013.

Cheng, K., Wang, Y., Tian, H., Gao, X., Zhang, Y., Wu, X., Zhu, C., and Gao, J.: Atmospheric Emission Characteristics and Control Policies of Five Precedent-Controlled Toxic Heavy Metals from Anthropogenic Sources in China, Environ. Sci. Technol., 49, 1206-1214, doi:10.1021/es5037332, 2015.

Cheung, K., Shafer, M. M., Schauer, J. J., and Sioutas, C.: Diurnal trends in oxidative potential of coarse particulate matter in the Los Angeles Basin and their relation to sources and chemical composition, Environ. Sci. Technol., 46, 3779-3787, doi:10.1021/es204211v, 2012.

Clements, A. L., Buzcu-Guven, B., Fraser, M. P., Kulkarni, P., and Chellam, S.: Role of particulate metals in heterogenous secondary sulfate formation, Atmos. Environ., 75, 233-240, doi:10.1016/j.atmosenv.2013.04.038, 2013.

Costa, D. L. and Dreher, K. L.: Bioavailable transition metals in particulate matter mediate cardiopulmonary injury in healthy and compromised animal models, Environ. Health Perspect., 105, 1053-1060, 1997.

Deguillaume, L., Leriche, M., Monod, A., and Chaumerliac, N.: The role of transition metal ions on $\mathrm{HO}_{\mathrm{x}}$ radicals in clouds: a numerical evaluation of its impact on multiphase chemistry, Atmos. Chem. Phys., 4, 95-110, doi:10.5194/acp-4-95-2004, 2004.

Deguillaume, L., Leriche, M., Desboeufs, K., Mailhot, G., George, C., and Chaumerliac, N.: Transition metals in atmospheric liquid phases: Sources, reactivity, and sensitive parameters, Chem. Rev., 105, 3388-3431, doi:10.1021/cr040649c, 2005.

Demoz, B. B., Collett Jr., J. L., and Daube Jr., B. C.: On the Caltech active strand cloudwater collectors, Atmos. Res., 41, 47-62, doi:10.1016/0169-8095(95)00044-5, 1996.

Deng, C., Zhuang, G., Huang, K., Li, J., Zhang, R., Wang, Q., Liu, T., Sun, Y., Guo, Z., Fu, J. S., and Wang, Z.: Chemical character- ization of aerosols at the summit of Mountain Tai in Central East China, Atmos. Chem. Phys., 11, 7319-7332, doi:10.5194/acp11-7319-2011, 2011.

Desboeufs, K. V., Losno, R., and Colin, J. L.: Factors influencing aerosol solubility during cloud processes, Atmos. Environ., 35, 3529-3537, doi:10.1016/S1352-2310(00)00472-6, 2001.

Draxler, R. R. and Rolph, G. D.: HYSPLIT (HYbrid Single-Particle Lagrangian Integrated Trajectory) Model access via NOAA ARL READY Website, available at: http://www.arl.noaa.gov/ HYSPLIT.php (last access: 1 February 2015), NOAA Air Resources Laboratory, College Park, MD, 2014.

Fang, G. C., Huang, Y. L., and Huang, J. H.: Study of atmospheric metallic elements pollution in Asia during 2000-2007, J. Hazard. Mater., 180, 115-121, doi:10.1016/j.jhazmat.2010.03.120, 2010.

Fomba, K. W., Müller, K., van Pinxteren, D., and Herrmann, H. Aerosol size-resolved trace metal composition in remote northern tropical Atlantic marine environment: case study Cape Verde islands, Atmos. Chem. Phys., 13, 4801-4814, doi:10.5194/acp13-4801-2013, 2013.

Gieré, R., Blackford, M., and Smith, K.: TEM study of PM2. 5 emitted from coal and tire combustion in a thermal power station, Environ. Sci. Technol., 40, 6235-6240, 2006.

Guo, J., Tilgner, A., Yeung, C., Wang, Z., Louie, P. K., Luk, C. W., Xu, Z., Yuan, C., Gao, Y., Poon, S., Herrmann, H., Lee, S., Lam, K. S., and Wang, T.: Atmospheric peroxides in a polluted subtropical environment: seasonal variation, sources and sinks, and importance of heterogeneous processes, Environ. Sci. Technol., 48, 1443-1450, doi:10.1021/es403229x, 2014a.

Guo, L., Chen, Y., Wang, F., Meng, X., Xu, Z., and Zhuang, G.: Effects of Asian dust on the atmospheric input of trace elements to the East China Sea, March Chem., 163, 19-27, doi:10.1016/j.marchem.2014.04.003, 2014b.

Harris, E., Sinha, B., van Pinxteren, D., Tilgner, A., Fomba, K. W., Schneider, J., Roth, A., Gnauk, T., Fahlbusch, B., Mertes, S., Lee, T., Collett, J., Foley, S., Borrmann, S., Hoppe, P., and Herrmann, H.: Enhanced role of transition metal ion catalysis during in-cloud oxidation of $\mathrm{SO}_{2}$, Science, 340, 727-730, doi:10.1126/science.1230911, 2013.

Heal, M. R., Hibbs, L. R., Agius, R. M., and Beverland, I. J.: Total and water-soluble trace metal content of urban background PM10, PM2.5 and black smoke in Edinburgh, UK, Atmos. Environ., 39, 1417-1430, doi:10.1016/j.atmosenv.2004.11.026, 2005.

Hoek, G., Krishnan, R. M., Beelen, R., Peters, A., Ostro, B., Brunekreef, B., and Kaufman, J. D.: Long-term air pollution exposure and cardio-respiratory mortality: a review, Environ. Health-Glob., 12, 43, doi:10.1186/1476-069X-12-43, 2013.

Hopke, P., Barrie, L., Li, S. M., Cheng, M. D., Li, C., and Xie, Y.: Possible sources and preferred pathways for biogenic and nonsea-salt sulfur for the high Arctic, J. Geophys. Res.-Atmos., 100, 16595-16603, 1995.

Hsu, S.-C., Lin, F.-J., and Jeng, W.-L.: Seawater solubility of natural and anthropogenic metals within ambient aerosols collected from Taiwan coastal sites, Atmos. Environ., 39, 3989-4001, doi:10.1016/j.atmosenv.2005.03.033, 2005.

Hsu, S.-C., Wong, G. T. F., Gong, G.-C., Shiah, F.-K., Huang, Y.T., Kao, S.-J., Tsai, F., Candice Lung, S.-C., Lin, F.-J., Lin, I. I., Hung, C.-C., and Tseng, C.-M.: Sources, solubility, and dry deposition of aerosol trace elements over the East China Sea, March 
Chem., 120, 116-127, doi:10.1016/j.marchem.2008.10.003, 2010.

Hsu, S.-C., Lin, F.-J., Liu, T.-H., Lin, S.-H., Kao, S.-J., Tseng, C.-M., and Huang, C.-H.: Short time dissolution kinetics of refractory elements $\mathrm{Fe}, \mathrm{Al}$, and $\mathrm{Ti}$ in Asian outflow-impacted marine aerosols and implications, Atmos. Environ., 79, 93-100, doi:10.1016/j.atmosenv.2013.06.037, 2013.

Hu, X., Zhang, Y., Ding, Z., Wang, T., Lian, H., Sun, Y., and $\mathrm{Wu}, \mathrm{J} .:$ Bioaccessibility and health risk of arsenic and heavy metals $(\mathrm{Cd}, \mathrm{Co}, \mathrm{Cr}, \mathrm{Cu}, \mathrm{Ni}, \mathrm{Pb}, \mathrm{Zn}$ and $\mathrm{Mn})$ in TSP and PM2.5 in Nanjing, China, Atmos. Environ., 57, 146-152, doi:10.1016/j.atmosenv.2012.04.056, 2012.

Husain, L., Ghauri, B., Yang, K., Khan, A. R., and Rattigan, O. V.: Application of the SO42-/Se tracer technique to study SO2 oxidation in cloud and fog on a time scale of minutes, Chemosphere, 54, 177-183, doi:10.1016/s0045-6535(03)00531-9, 2004.

Jakob, A., Stucki, S., and Kuhn, P.: Evaporation of Heavy Metals during the Heat Treatment of Municipal Solid Waste Incinerator Fly Ash, Environ. Sci. Technol., 29, 2429-2436, doi:10.1021/es00009a040, 1995.

Jickells, T. D., An, Z. S., Andersen, K. K., Baker, A. R., Bergametti, G., Brooks, N., Cao, J. J., Boyd, P. W., Duce, R. A., Hunter, K. A., Kawahata, H., Kubilay, N., laRoche, J., Liss, P. S., Mahowald, N., Prospero, J. M., Ridgwell, A. J., Tegen, I., and Torres, R.: Global iron connections between desert dust, ocean biogeochemistry, and climate, Science, 308, 67-71, doi:10.1126/science.1105959, 2005.

Kaufman, Y. J., Tanré, D., and Boucher, O.: A satellite view of aerosols in the climate system, Nature, 419, 215-223, 2002.

Li, W., Li, P., Sun, G., Zhou, S., Yuan, Q., and Wang, W.: Cloud residues and interstitial aerosols from non-precipitating clouds over an industrial and urban area in northern China, Atmos. Environ., 45, 2488-2495, doi:10.1016/j.atmosenv.2011.02.044, 2011.

Li, W., Wang, Y., Collett Jr., J. L., Chen, J., Zhang, X., Wang, Z., and Wang, W.: Microscopic evaluation of trace metals in cloud droplets in an Acid precipitation region, Environ. Sci. Technol., 47, 4172-4180, doi:10.1021/es304779t, 2013.

Li, W., Chi, J., Shi, Z., Wang, X., Chen, B., Wang, Y., Li, T., Chen, J., Zhang, D., Wang, Z., Shi, C., Liu, L., and Wang, W.: Composition and hygroscopicity of aerosol particles at Mt. Lu in South China: Implications for acid precipitation, Atmos. Environ., 94, 626-636, doi:10.1016/j.atmosenv.2014.06.003, 2014.

Mackie, D. S., Peat, J. M., McTainsh, G. H., Boyd, P. W., and Hunter, K. A.: Soil abrasion and eolian dust production: Implications for iron partitioning and solubility, Geochem. Geophys. Geosyst., 7, 1-11, doi:10.1029/2006gc001404, 2006.

Mahowald, N.: Aerosol indirect effect on biogeochemical cycles and climate, Science, 334, 794-796, doi:10.1126/science.1207374, 2011.

Moreno, T., Querol, X., Alastuey, A., Reche, C., Cusack, M., Amato, F., Pandolfi, M., Pey, J., Richard, A., Prévôt, A. S. H., Furger, M., and Gibbons, W.: Variations in time and space of trace metal aerosol concentrations in urban areas and their surroundings, Atmos. Chem. Phys., 11, 9415-9430, doi:10.5194/acp-11-94152011, 2011.

Newman, L.: Atmospheric oxidation of sulfur dioxide: A review as viewed from power plant and smelter plume studies, Atmos. Environ.,, 15, 2231-2239, doi:10.1016/0004-6981(81)90255-9, 1981.
Oakes, M., Ingall, E. D., Lai, B., Shafer, M. M., Hays, M. D., Liu, Z. G., Russell, A. G., and Weber, R. J.: Iron solubility related to particle sulfur content in source emission and ambient fine particles, Environ. Sci. Technol., 46, 6637-6644, doi:10.1021/es300701c, 2012.

Polissar, A. V., Hopke, P. K., and Harris, J. M.: Source regions for atmospheric aerosol measured at Barrow, Alaska, Environ. Sci. Technol., 35, 4214-4226, 2001.

Querol, X., Viana, M., Alastuey, A., Amato, F., Moreno, T., Castillo, S., Pey, J., de la Rosa, J., Sánchez de la Campa, A., Artíñano, B., Salvador, P., García Dos Santos, S., Fernández-Patier, R., Moreno-Grau, S., Negral, L., Minguillón, M. C., Monfort, E., Gil, J. I., Inza, A., Ortega, L. A., Santamaría, J. M., and Zabalza, J.: Source origin of trace elements in PM from regional background, urban and industrial sites of Spain, Atmos. Environ., 41, 7219-7231, doi:10.1016/j.atmosenv.2007.05.022, 2007.

Quispe, D., Pérez-López, R., Silva, L. F. O., and Nieto, J. M.: Changes in mobility of hazardous elements during coal combustion in Santa Catarina power plant (Brazil), Fuel, 94, 495-503, doi:10.1016/j.fuel.2011.09.034, 2012.

Reff, A., Bhave, P., Simon, H., Pace, T. G., Pouliot, G. A., Mobley, J. D., and Houyoux, M.: Emissions Inventory of PM2.5 Trace Elements across the United States, Environ. Sci. Technol., 43, 5790-5796, doi:10.1021/es802930x, 2009.

Ren, L., Wang, W., Wang, Q., Yang, X., and Tang, D.: Comparison and trend study on acidity and acidic buffering capacity of particulate matter in China, Atmos. Environ., 45, 7503-7519, doi:10.1016/j.atmosenv.2010.08.055, 2011.

Rubasinghege, G., Lentz, R. W., Scherer, M. M., and Grassian, V. H.: Simulated atmospheric processing of iron oxyhydroxide minerals at low $\mathrm{pH}$ : roles of particle size and acid anion in iron dissolution, Proc. Natl. Acad. Sci. USA, 107, 6628-6633, doi:10.1073/pnas.0910809107, 2010.

Schulz, M., Prospero, J. M., Baker, A. R., Dentener, F., Ickes, L., Liss, P. S., Mahowald, N. M., Nickovic, S., Garcia-Pando, C. P., Rodriguez, S., Sarin, M., Tegen, I., and Duce, R. A.: Atmospheric transport and deposition of mineral dust to the ocean: implications for research needs, Environ. Sci. Technol., 46, 1039010404, doi:10.1021/es300073u, 2012.

Schwab, J. J.: Aerosol chemical composition in New York state from integrated filter samples: Urban/rural and seasonal contrasts, J. Geophys. Res., 109, D16S05, doi:10.1029/2003jd004078, 2004.

Seinfeld, J. H. and Pandis, S. N.: Atmospheric chemistry and physics: from air pollution to climate change, John Wiley \& Sons, New Jersey, 2012.

Shafer, M. M., Perkins, D. A., Antkiewicz, D. S., Stone, E. A., Quraishi, T. A., and Schauer, J. J.: Reactive oxygen species activity and chemical speciation of size-fractionated atmospheric particulate matter from Lahore, Pakistan: an important role for transition metals, J. Environ. Monitor., 12, 704-715, 2010.

Shi, Z., Krom, M. D., Bonneville, S., Baker, A. R., Jickells, T. D., and Benning, L. G.: Formation of iron nanoparticles and increase in iron reactivity in mineral dust during simulated cloud processing, Environ. Sci. Technol., 43, 6592-6596, 2009.

Solmon, F., Chuang, P. Y., Meskhidze, N., and Chen, Y.: Acidic processing of mineral dust iron by anthropogenic compounds over the north Pacific Ocean, J. Geophys. Res., 114, D02305, doi:10.1029/2008jd010417, 2009. 
Spokes, L. J., Jickells, T. D., and Lim, B.: Solubilisation of aerosol trace metals by cloud processing: A laboratory study, Geochim. Cosmochim. Acta, 58, 3281-3287, doi:10.1016/00167037(94)90056-6, 1994.

Takahashi, Y., Higashi, M., Furukawa, T., and Mitsunobu, S.: Change of iron species and iron solubility in Asian dust during the long-range transport from western China to Japan, Atmos. Chem. Phys., 11, 11237-11252, doi:10.5194/acp-1111237-2011, 2011.

Tian, H., Gao, J., Lu, L., Zhao, D., Cheng, K., and Qiu, P.: Temporal trends and spatial variation characteristics of hazardous air pollutant emission inventory from municipal solid waste incineration in China, Environ. Sci. Technol., 46, 10364-10371, doi:10.1021/es302343s, 2012.

Tian, H., Liu, K., Zhou, J., Lu, L., Hao, J., Qiu, P., Gao, J., Zhu, C., Wang, K., and Hua, S.: Atmospheric emission inventory of hazardous trace elements from China's coal-fired power plantstemporal trends and spatial variation characteristics, Environ. Sci. Technol., 48, 3575-3582, doi:10.1021/es404730j, 2014.

Wang, Y., Zhang, X., and Draxler, R. R.: TrajStat: GIS-based software that uses various trajectory statistical analysis methods to identify potential sources from long-term air pollution measurement data, Environ. Model. Soft., 24, 938-939, 2009.

Wei, F., Chen, J., Wu, Y., and Zheng, C.: Study of the background contents of 61 elements of soils in China, Environmental Science, 12, 12-19, 1991 (in Chinese).

Weichenthal, S., Villeneuve, P. J., Burnett, R. T., van Donkelaar, A., Martin, R. V., Jones, R. R., DellaValle, C. T., Sandler, D. P., Ward, M. H., and Hoppin, J. A.: Long-term exposure to fine particulate matter: association with nonaccidental and cardiovascular mortality in the agricultural health study cohort, Environ. Health Perspect., 122, 609-615, doi:10.1289/ehp.1307277, 2014.
Wen, H. and Carignan, J.: Review on atmospheric selenium: Emissions, speciation and fate, Atmos. Environ., 41, 7151-7165, doi:10.1016/j.atmosenv.2007.07.035, 2007.

Werner, M. L., Nico, P. S., Marcus, M. A., and Anastasio, C.: Use of Micro-XANES to Speciate Chromium in Airborne Fine Particles in the Sacramento Valley, Environ. Sci. Technol., 41, 4919-4924, doi:10.1021/es070430q, 2007.

Xu, H. M., Cao, J. J., Ho, K. F., Ding, H., Han, Y. M., Wang, G. H., Chow, J. C., Watson, J. G., Khol, S. D., Qiang, J., and Li, W. T.: Lead concentrations in fine particulate matter after the phasing out of leaded gasoline in Xi' an, China, Atmos. Environ., 46, 217 224, doi:10.1016/j.atmosenv.2011.09.078, 2012.

Yang, F., Tan, J., Zhao, Q., Du, Z., He, K., Ma, Y., Duan, F., Chen, G., and Zhao, Q.: Characteristics of $\mathrm{PM}_{2.5}$ speciation in representative megacities and across China, Atmos. Chem. Phys., 11, 5207-5219, doi:10.5194/acp-11-5207-2011, 2011.

Yang, Y., Wang, Y., Wen, T., Li, W., Zhao, Y., and Li, L.: Elemental composition of PM2.5 and PM10 at Mount Gongga in China during 2006, Atmos. Res., 93, 801-810, doi:10.1016/j.atmosres.2009.03.014, 2009a.

Yang, Y., Wang, Y., Wen, T., Zhao, Y., and Li, J.: Element Characterisitics and Sources of PM2.5 at Mount Dinghu in 2006, Environmental Science, 30, 988-992, 2009b (in Chinese).

Zhang, Q., Streets, D. G., Carmichael, G. R., He, K. B., Huo, H., Kannari, A., Klimont, Z., Park, I. S., Reddy, S., Fu, J. S., Chen, D., Duan, L., Lei, Y., Wang, L. T., and Yao, Z. L.: Asian emissions in 2006 for the NASA INTEX-B mission, Atmos. Chem. Phys., 9, 5131-5153, doi:10.5194/acp-9-5131-2009, 2009. 